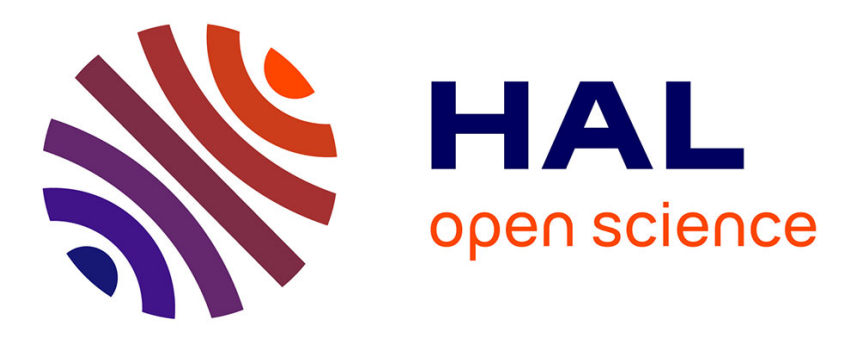

\title{
Heavy vehicles on the road towards the circular economy: Analysis and comparison with the automotive industry
}

\author{
Michael Saidani, Bernard Yannou, Yann Leroy, François Cluzel
}

\section{To cite this version:}

Michael Saidani, Bernard Yannou, Yann Leroy, François Cluzel. Heavy vehicles on the road towards the circular economy: Analysis and comparison with the automotive industry. Resources, Conservation and Recycling, 2018, 10.1016/j.resconrec.2017.06.017 . hal-01571577

\section{HAL Id: hal-01571577 \\ https://hal.science/hal-01571577}

Submitted on 2 Aug 2017

HAL is a multi-disciplinary open access archive for the deposit and dissemination of scientific research documents, whether they are published or not. The documents may come from teaching and research institutions in France or abroad, or from public or private research centers.
L'archive ouverte pluridisciplinaire HAL, est destinée au dépôt et à la diffusion de documents scientifiques de niveau recherche, publiés ou non, émanant des établissements d'enseignement et de recherche français ou étrangers, des laboratoires publics ou privés. 
To cite this version: Michael Saidani, Bernard Yannou, Yann Leroy, François Cluzel, Heavy vehicles on the road towards the circular economy: Analysis and comparison with the automotive industry, Resources, Conservation and Recycling, 2017, ISSN 0921-3449, http://dx.doi.org/10.1016/j.resconrec.2017.06.017.

\title{
Heavy Vehicles on the Road to the Circular Economy: Analysis and Comparison with the Automotive Industry
}

\author{
Submitted to: Resources, Conservation and Recycling, Special Issue on the Circular Economy, January 2017.
}

Word count: 14857 words including references and appendix, 11217 without references and appendix.

\section{Authors' names and affiliations:}

Michael Saidani ${ }^{1}$, Bernard Yannou ${ }^{1}$, Yann Leroy ${ }^{1}$, François Cluzel ${ }^{1}$

${ }^{1}$ Laboratoire Genie Industriel, CentraleSupélec, Université Paris-Saclay

Contact author: michael.saidani@centralesupelec.fr

\section{Abstract:}

With 270 million light vehicles and 20 million heavy-duty and off-road (HDOR) vehicles in use in the European Union, the automotive and HDOR industries form two major sectors of the European economy. Each year, 12 million light vehicles plus 1 million HDOR vehicles reach the end of their lives. In a circular economy perspective, the following two questions are of growing concern: (i) to what extent is the circular economy achieved and implemented in the automotive and HDOR sectors? (ii) what industrial practices and regulations are prevalent and commendable for the circular economy? The end-of-life management of light vehicles (subject to the ELV Directive 2000/53/EC) has been widely studied in the literature, but the endof-life stage of HDOR vehicles has long been neglected by researchers. To fill this gap, both extensive literature survey and in-depth industrial investigations were conducted. Key factors, i.e. regulations, business models and market evolution, and integration of new emerging technologies affecting the circular economy performance of the automotive and HDOR sectors were analysed. Lessons learned from best industrial practices are highlighted, and remaining challenges for a more circular economy are identified. The two industries are compared in terms of the four buildings blocks of the circular economy and the four possible feedback loops defined by the Ellen MacArthur Foundation. This research contribution can lead on to practical applications, e.g. help industrial practitioners and policy makers take up the challenges and seize opportunities to close the loops for HDOR vehicles through different approaches.

\section{Key words:}

Circular Economy; Automotive; Heavy Vehicles; End-of-Life Management; CE strategies; CE implementation.

Highlights:

- In-depth study reveals huge potential to develop CE solutions in the heavy vehicles sector.

- Impacts of regulations, business models, and emerging technologies are analysed for CE performance.

- Best industrial practices and remaining challenges are examined for a CE of light and heavy vehicles.

- Streamlined, well-controlled dismantling, reuse and recycling are preferred options for the automotive industry.

- Uneven but growing remanufacturing and loosely controlled exports are preferred options for the HDOR industry.

\section{INTRODUCTION AND BACKGROUND}

Climate change, global warming, and the depletion of natural resources from anthropic root causes can no longer be contested, as highlighted in numerous Intergovernmental Panel on Climate Change reports (IPCC, 2014; IPCC, 2015). Thus optimal designs, uses and management of resources and systems are more than ever essential to protect human societies and ensure biodiversity. Furthermore, as reported by the McKinsey Commodity Price Index (MGI, 2013), resource prices have increased significantly since the turn of the 21th century. The dependence of industries on raw materials, such as precious or rare metals, presents highly strategic challenges for supply management. Besides shortages of metals and their supply challenges in Europe, the rise in global demand for raw materials has created extraordinary price volatility (Hagelüken et al., 2016).

For the automotive and heavy-duty and off-road (HDOR) vehicle industries, these added costs are increasing by several million euros from one year to the next (ACEA, 2015). With 270 million light vehicles (passenger cars and light commercial vehicles) and 20 million HDOR vehicles in use in Europe (ICCT, 2016), the automotive and HDOR sectors are two industrial giants in Europe. Their ever-growing economic and environmental footprints are uncontested: the turnover generated by the automotive sector represents $6.5 \%$ of the European Union (EU) gross domestic product, and more than 12 million people are employed in the sector (ACEA, 2016). Being able to forestall shortages and secure supplies of raw materials is of the utmost importance for manufacturers (Sievers and Tercero, 2012). Equally, the geopolitical issues around raw materials and resource efficiency are being 
To cite this version: Michael Saidani, Bernard Yannou, Yann Leroy, François Cluzel, Heavy vehicles on the road towards the circular economy: Analysis and comparison with the automotive industry, Resources, Conservation and Recycling, 2017, ISSN 0921-3449, http://dx.doi.org/10.1016/j.resconrec.2017.06.017.

integrated at the EU level (EC, 2010; EC, 2011; EC, 2014a; EC, 2015). Some 12 million light vehicles plus 1 million heavy vehicles are taken off the roads every year in the EU, which amounts to millions of tonnes of what actually constitute valuable resources (EMF, 2013a; Weiland, 2014): automotive and HDOR manufacturers thus have a direct interest in more sustainable management of their products, components and materials in order to stay competitive in the face of price rises and volatility.

To support both economic growth and sustainable resource management, the circular economy (CE) paradigm offers rich opportunities for industrial practitioners: the promises and benefits expected from circular practices have been comprehensively discussed in the literature (EMF, 2013b; CIRAIG, 2015; MGI, 2015; Lacy, 2015; Ghisellini et al., 2016). CE is viewed as a restorative solution with the potential to eliminate waste (EC, 2015a; EEA, 2015, EEA, 2016); it can also both secure Europe's competitiveness and ensure benefits through the three pillars of sustainable development (Banaité, 2016; Sauvé et al., 2016; Geissdoerfer et al., 2017). In particular, the use of closed-loop approaches mitigates manufacturers' dependency on virgin materials, and attenuates price volatility (Kiser, 2016). Even so, some industrial fields still need help in their transition from a linear to a more circular economy: companies may lack capacity, information, indicators and targets to move toward CE solutions (EASAC, 2016). To date, much more attention has been paid to end-of-life management in the automotive sector than in the HDOR sector.

End-of-life (EoL) management and recycling issues for cars, i.e. in the automotive sector, have been extensively studied in the literature in the last two decades from different perspectives (Tukker and Cohen, 2004; Wells and Orsato, 2005; Reuter et al., 2006; Froelich et al., 2007; Chemineau, 2011; Millet et al., 2012; Farel et al., 2013; Yi and Park, 2015; El Halabi, 2015; Despeisse et al., 2015; Simic, 2015; Idjis et al., 2017). By contrast, there is a current paucity of studies on waste minimisation and EoL for HDOR vehicles, which seems principally due to the absence of EoL regulations and extended producer responsibilities. Most of the research on HDOR vehicles has focused on the design and use phase of heavy vehicles. This approach is justified, since some $80 \%$ of the total environmental impact throughout the entire life cycle of vehicles, light or heavy, is generated during the use phase (Hill et al., 2012; Manitou Group, 2016). Current US and EU improvement road maps related to HDOR vehicles barely address the EoL value chain of HDOR vehicles, and instead emphasise optimising the design and use phases (ERTRAC, 2012; USDoE, 2013; Poulikakos et al., 2013): research work focuses mainly on saving fuel during the use phase (Walnum and Simonsen, 2015), mitigating emissions (ERTRAC, 2012), and integrating lightweight materials (USDoE, 2013).

The EoL management of HDOR vehicles is nonetheless an important issue for research and industry, whose readiness to identify unexploited or wasted opportunities is a prerequisite for further progress. The preliminary field diagnosis that prompted and steered our research in the HDOR sector, in a CE perspective, identified the following two drivers:

- Tonnage of EoL HDOR vehicles is of the same order of magnitude as that of EoL ELVs in Europe. This tonnage is around 1 million tons in France (ADEME, 2006). Hence the economic, environmental and social stakes in the HDOR industry are potentially at least as high as in the automotive industry, and so constitute a significant area for job creation and improvement, of importance to both public policy makers and industrial practitioners;

- Lack of current regulations for the EoL of HDOR vehicles comparable to the ELV Directive 2000/53/EC in force, should urge watchful industrial practitioners to plan ahead for likely future or emerging regulations.

On this basis, the HDOR sector can be meaningfully positioned in a move towards CE. This paper offers a comprehensive overview of the situation and progress of the HDOR industry in Europe in a CE perspective. It reports on existing initiatives and incentives from the HDOR industry in line with CE principles. In particular, it highlights emerging approaches, such as new integrated technologies or innovative business models in their contributions and impacts in CE. The situation and progress of the automotive industry will also be examined as a benchmark to learn from best practices. Based on both an in-depth literature review through different types of resources, e.g. academic papers, industrial, government and consulting reports, company websites, and investigations in the industrial field, key insights and answers to the following questions will be presented: 
To cite this version: Michael Saidani, Bernard Yannou, Yann Leroy, François Cluzel, Heavy vehicles on the road towards the circular economy: Analysis and comparison with the automotive industry, Resources, Conservation and Recycling, 2017, ISSN 0921-3449, http://dx.doi.org/10.1016/j.resconrec.2017.06.017.

- To what degree is CE achieved and implemented in the automotive and HDOR sectors?

- What CE-compatible practices already exist for these sectors?

- How do existing policy frameworks foster the move towards CE?

In what follows, these questions are studied with reference to the four building block CE model defined by the Ellen MacArthur Foundation (EMF, 2013b).

This paper is organised as follows. Section 2.1 defines the terms and boundaries of the study. Section 2.2 describes the research methodology and investigations undertaken to obtain a comprehensive view of the automotive and HDOR sectors in a CE perspective. Section 2.3 details comparison criteria to evaluate the automotive and HDOR industries with regard to CE. In Section 3 , several key factors affecting the CE performance of both the automotive and the HDOR sectors are analysed. Relevant insights from industrial companies are also presented. In particular, the end of Section 3 reviews best practices and remaining challenges in these two sectors in their movement towards an efficient and effective CE. Finally, Section 4 points to relevant research perspectives for further work to support a shift from a linear to a more circular economy in the automotive and HDOR industries.

\section{MATERIAL AND METHODS}

\subsection{DEFINITIONS, SCOPE AND BOUNDARIES OF THE STUDY}

\subsubsection{Distinction between light (automotive sector) and heavy (HDOR sector) vehicles}

The automotive sector encompasses motor road vehicles weighing less than 3.5 tons and is covered by the ELV Directive 2000/53/EC in Europe. Less simply, heavy-duty and off-road (HDOR) vehicles are composed of two categories, namely heavy-duty vehicles (HDVs), mainly trucks, and non-road mobile machinery (NRMM), mainly agricultural and construction machinery (EC and ERN, 2015). HDV classifications are typically based on the maximum loaded weight of the truck, typically using the gross vehicle weight rating (GVWR), and they vary by geographical location; for instance US and EU classifications are different. GVWR is defined as the maximum allowable total weight of a road vehicle or trailer that is loaded, including the weight of the vehicle. The UK Vehicle Type Approval Agency calls NRMM any mobile machine, or item of transportable industrial equipment not intended for carrying passengers or goods on the road, and powered by a combustion engine (DfT, 2016). In the grey literature HDVs and NRMM are usually brought together under the term HDOR, because of their similar regulations, emissions, materials, mass, and components: HDOR $=\mathrm{HDV}+\mathrm{NRMM}$.

The HDOR industry includes firms that manufacture and remanufacture components or parts of off-highway equipment generally used in the construction, farming, mining, and oil and gas drilling industries. HDOR equipment is therefore much more diverse than vehicles in the automotive sector: in contrast to light vehicles, the HDV sector covers all types of trucks weighing more than 3.5 tons, while the NRMM sector covers a very broad range of machinery, including construction machinery (e.g. excavators, compactors, loaders, dumpers, bulldozers and mobile cranes), and agricultural and farming machinery (e.g. harvesters and cultivators). Common and specific features of automotive and HDOR sectors are summarised in Table 1.

Table 1 - Definitions and features of automotive and HDOR sectors

\begin{tabular}{|l|l|l|l|}
\hline & Automotive sector & \multicolumn{2}{|l|}{ Heavy-Duty and Off-Road (HDOR) sector } \\
\hline Sub-category & Light Vehicles & Heavy-Duty Vehicles (HDVs) & $\begin{array}{l}\text { Non-Road Mobile Machinery } \\
\text { (NRMM) }\end{array}$ \\
\hline Definition & $\begin{array}{l}\text { Road vehicles weighing } \\
\text { less than 3.5 tons (Directive } \\
\text { 2000/53/EC). }\end{array}$ & $\begin{array}{l}\text { Nominally defined as vehicles } \\
\text { weighing more than 3.5 } \\
\text { metric tons (UNECE, 2016). }\end{array}$ & $\begin{array}{l}\text { Mobile machines not intended } \\
\text { for carrying passengers or } \\
\text { goods on the road, and } \\
\text { powered by a combustion } \\
\text { engine (DfT, 2016). }\end{array}$ \\
\hline
\end{tabular}


To cite this version: Michael Saidani, Bernard Yannou, Yann Leroy, François Cluzel, Heavy vehicles on the road towards the circular economy: Analysis and comparison with the automotive industry, Resources, Conservation and Recycling, 2017, ISSN 0921-3449, http://dx.doi.org/10.1016/j.resconrec.2017.06.017.

\begin{tabular}{|l|l|l|l|}
\hline Examples & $\begin{array}{l}\text { Passenger cars \& } \\
\text { commercial-light vehicles. }\end{array}$ & Trucks, buses. & Tractors, excavators. \\
\hline $\begin{array}{l}\text { Applications, markets, } \\
\text { usage. }\end{array}$ & $\begin{array}{l}\text { Mainly private individuals } \\
\text { for daily use. } \\
\text { Mainly BtoC (business to } \\
\text { consumer). }\end{array}$ & $\begin{array}{l}\text { Mainly used for commercial } \\
\text { purposes, notably for freight } \\
\text { (ICCT, 2015). } \\
\text { Mainly BtoB (business to } \\
\text { business). }\end{array}$ & $\begin{array}{l}\text { Agriculture, construction, } \\
\text { mining and forestry. } \\
\text { Mainly BtoB (business to } \\
\text { business). }\end{array}$ \\
\hline Final owners & $\begin{array}{l}\text { Private individuals, } \\
\text { garages, insurers. }\end{array}$ & $\begin{array}{l}\text { Transport and freight } \\
\text { companies. }\end{array}$ & $\begin{array}{l}\text { Civil engineering, mining and } \\
\text { rental companies. }\end{array}$ \\
\hline Major constructors & $\begin{array}{l}\text { Toyota, Volkswagen, } \\
\text { Renault. }\end{array}$ & $\begin{array}{l}\text { Volvo Truck, MAN, Daimler, } \\
\text { Scania, DAF. }\end{array}$ & $\begin{array}{l}\text { Caterpillar, Komatsu, Volvo CE, } \\
\text { John Deere, Liebherr, JCB. }\end{array}$ \\
\hline Main figures & $\begin{array}{l}\text { 270 million light vehicles in } \\
\text { use in Europe (ICCT 2016). }\end{array}$ & $\begin{array}{l}7 \text { million trucks and trailers } \\
\text { (from 3.6 to 40 tons) in use in } \\
\text { Europe (ICCT, 2016). }\end{array}$ & $\begin{array}{l}\text { 10 million agriculture tractors, 2 } \\
\text { million off-road, construction } \\
\text { and mining vehicles in use in } \\
\text { Europe (Weiland, 2014). }\end{array}$ \\
\hline & $\begin{array}{l}\text { Eund } \\
\text { 12 million ELV in Europe } \\
\text { each year (EMF, 2013a) }\end{array}$ & $\begin{array}{l}\text { Around 1 million EoL HDOR units in Europe each year (Weiland, } \\
\text { 2014). }\end{array}$ \\
\hline
\end{tabular}

\subsubsection{Geographical scope}

The geographical scope of the study is limited to the EU (28 Member States) for the following reasons: (i) automotive and HDOR markets are large in the EU, (ii) EU environmental regulations are among the most stringent in the world, offering a gold standard for other countries, which are usually moving towards what is current in the EU in terms of regulations, (iii) the authors of the present paper are located in France, and the stakeholders interviewed were mostly based in Europe. Thus the European situation could be expected to provide a sound basis for gaining an understanding of the position and issues of the automotive and HDOR sectors in a CE perspective.

\subsection{RESEARCH METHODOLOGY}

To cover the automotive and HDOR industries broadly and conduct an extensive research study throughout the whole value chain, from a multi-actor viewpoint in a CE perspective, a multimethod research approach (Creswell, 2003) was implemented. Creswell and Plano Clark (2007) define multi-method research as combined-method study in which a researcher uses multiple methods of data collection and analysis. Mixed-method research offers several advantages: (i) triangulation, i.e. seeking convergence of findings, (ii) complementarity, i.e. overlapping different facets of an issue, and (iii) development potential, i.e. the first method is used sequentially as input to the second method (Clarke, 2005). Here, two main types of research were used: desk-based and field-based.

Our desk-based research comprised a literature review, library research, database research and online research using key words. Diversifying the sources was essential here, because the main information and data concerning the EoL of HDOR vehicles cannot be obtained via the scant academic literature published on the subject: much relevant information was thus gathered through industrial, government and consulting agency reports, and from the internet websites of HDOR actors.

Our field-based research was through direct contact with the industrial reality through a 5month internship at a major NRMM manufacturer, surveys, face-to-face meetings, telephone interviews, and attendance at workshops and conferences related to the subject. Field-based research was essential in this study because state-of-the-art information is owned by industrial companies: meetings or teleconference interviews with diverse stakeholders linked to HDOR vehicles were useful not only to confirm, validate or challenge the information found in the literature, but also to collect new complementary information, data, and expert impressions or opinions, and find out more about existing collaborations between actors that could not have been gleaned from reports.

A detailed description of the multi-method research approach, including the variety of resources used for data collection, is given in Table 2 .

Table 2 - Description of the resources used in the multi-method research

\begin{tabular}{|l|l|l|}
\hline Resources used & \multicolumn{2}{l|}{ Description, details \& contributions } \\
\hline Desk-based research & $\begin{array}{l}\text { Field-based } \\
\text { research }\end{array}$ & $\begin{array}{l}\text { The following databases were used, some academic some not: Science } \\
\text { Direct, Web of Science, Scopus, Springer, Taylor \& Francis, Google } \\
\text { Scholar and Google. Keywords included combinations and variations of } \\
\text { terms such as: vehicle, heavy-duty, off-road, end-of-life, recycling, reuse, } \\
\text { remanufacturing, dismantling, disassembly, circular economy, circular }\end{array}$ \\
\hline
\end{tabular}


To cite this version: Michael Saidani, Bernard Yannou, Yann Leroy, François Cluzel, Heavy vehicles on the road towards the circular economy: Analysis and comparison with the automotive industry, Resources, Conservation and Recycling, 2017, ISSN 0921-3449, http://dx.doi.org/10.1016/j.resconrec.2017.06.017.

\begin{tabular}{|c|c|c|}
\hline & & $\begin{array}{l}\text { business model, circular product design, telematics, regulation, etc. } \\
\text { While the end-of-life management and impacts of cars have been widely } \\
\text { investigated and reviewed by scholars, e.g. around } 100 \text { peer-reviewed } \\
\text { journal articles on ELV recycling published between } 2003 \text { and } 2013 \\
\text { (Simic, 2013), the end-of-life of heavy vehicles has seldom been } \\
\text { addressed. }\end{array}$ \\
\hline Reports & & $\begin{array}{l}\text { Grey literature, such as reports and technical watches from government } \\
\text { and specialised agencies, private companies and consultants were also } \\
\text { reviewed, notably to make up for the paucity of information about HDOR } \\
\text { vehicles end-of-life and circular economy practices and implementation } \\
\text { in the academic literature. For instance, annual reports from major } \\
\text { HDOR equipment manufacturers (e.g. Volvo Group Sustainability Report } \\
\text { 2015) contain much relevant information on actual progress towards the } \\
\text { circular economy. }\end{array}$ \\
\hline Regulations & & $\begin{array}{l}\text { European regulations concerning automotive and HDOR sectors and } \\
\text { related, directly or indirectly, to the circular economy were reviewed. EU } \\
\text { regulations were available at: http://eur-lex.europa.eu. Reports from the } \\
\text { European Commission assessing the impact of certain regulations were } \\
\text { also reviewed. }\end{array}$ \\
\hline Websites & & $\begin{array}{l}\text { Major constructors' and manufacturers' websites were systematically } \\
\text { reviewed for remanufacturing, telematics, sustainability and the circular } \\
\text { economy. Online interviews with managers and videos about end-of-life } \\
\text { processing were also analysed to capture additional information. }\end{array}$ \\
\hline Datak & & $\begin{array}{l}\text { Information and statistics available on the Eurostat database website } \\
\text { were scanned to obtain an overview of the numbers of HDOR vehicles in } \\
\text { Europe, and their relative weighting compared with cars: } \\
\text { http://ec.europa.eu/eurostat/fr/data/database. }\end{array}$ \\
\hline INTERNSHIP & Internship & $\begin{array}{l}\text { A research internship was carried out at one of the major industrial } \\
\text { manufacturers of NRMM and spare parts in Europe. During the 5-month } \\
\text { internship, managers from different departments were met to discuss the } \\
\text { situation and action of the company on the road to the circular economy. }\end{array}$ \\
\hline & $\begin{array}{l}\text { Interviews: } \\
\text { - } \quad \text { in person } \\
\text { during planned } \\
\text { meetings; } \\
\text { - by audio. }\end{array}$ & $\begin{array}{l}\text { Interviews with field experts were conducted at different stages of the } \\
\text { study to confront desk-based research with industrial reality. The } \\
\text { interviews were conducted through a semi-structured questionnaire. A } \\
\text { generic questionnaire adaptable to the interviewee was designed: it is } \\
\text { given in Appendix A, along with the list of HDOR experts encountered. } \\
\text { Each consulted expert was systematically asked about their circular } \\
\text { practices. These interviews thus yielded indications of enablers and } \\
\text { barriers for improved end-of-life management and circular practices in } \\
\text { the HDOR sector. }\end{array}$ \\
\hline & Site visits & $\begin{array}{l}\text { A visit to an NRMM rental company was made. The director manager } \\
\text { was met, and gave his strategic view in a circular economy perspective. } \\
\text { The NRMM storage warehouse was also visited. }\end{array}$ \\
\hline & $\begin{array}{l}\text { Thematic day: } \\
\text { conference and } \\
\text { workshop }\end{array}$ & $\begin{array}{l}\text { Attendance at an annual academic-industrial meeting on the } \\
\text { responsibilities of actors for end-of-life vehicles. Discussions were also } \\
\text { extended to heavy vehicle end-of-life at a round table. }\end{array}$ \\
\hline
\end{tabular}

\subsection{CRITERIA TO COMPARE AUTOMOTIVE AND HDOR SECTORS THROUGH THE LENS OF THE CIRCULAR ECONOMY}

To analyse the situation of both the automotive and the HDOR sectors in a CE perspective, two plementary approaches were used. First, as there are several ways to close the loop (cf. Lansink's waste hierarchy ladder developed in 1979) (Parto et al., 2007; Recycling, 2016), the different pathways that help close the loops are used as criteria for comparison. The four possible feedback loops in the circular economy butterfly diagram proposed by the Ellen MacArthur Foundation (EMF, 2013b), were scrutinised, namely: (i) maintain or prolong, (ii) reuse, (iii) remanufacture or refurbish, and (iv) recycle.

Additionally, to complete this focus on EoL loops and encompass the CE paradigm more broadly, current situations and practices in the automotive and HDOR sectors were also analysed in terms of the CE building blocks defined by the EMF (2013b). The shift toward a more circular economy involves four fundamental building blocks, namely: (i) circular product design, (ii) new business models, (iii) reverse networks, and (iv) enablers and favourable system conditions. These comparison criteria were selected not only to ensure a systemic analysis of the CE concept applied to these two industrial sectors, but also because the CE model proposed by the EMF is one of the best known and most widely shared and acknowledged visions of $\mathrm{CE}$ among academics and industrial practitioners. 
To cite this version: Michael Saidani, Bernard Yannou, Yann Leroy, François Cluzel, Heavy vehicles on the road towards the circular economy: Analysis and comparison with the automotive industry, Resources, Conservation and Recycling, 2017, ISSN 0921-3449, http://dx.doi.org/10.1016/j.resconrec.2017.06.017.

In the following section, current EoL practices (sub-section 3.1), regulations (sub-section 3.2), business model evolution (sub-section 3.3), and promises and challenges of emerging technologies (sub-section 3.4) are used as comparison factors to set in parallel the situations and progress of the automotive and HDOR sectors on the road to CE. Insights from industrial practitioners (e.g. manufacturers) are also given to illustrate business strategies contributing to CE, and practical difficulties that still have to be overcome in a CE perspective. Finally, best practices and remaining challenges from both the automotive and the HDOR industries are summarised at the end of Section 3 for the four CE feedback loops and the four CE building blocks as described above (EMF, 2013b).

\section{RESULTS}

\subsection{CURRENT END-OF-LIFE SITUATIONS}

The contributions of reuse, remanufacturing, recycling and export were studied in both industries. As explained in detail below, whereas the EoL processing of the automotive sector is increasingly well-organised and fully formalised in the EU, the EoL management of HDOR vehicles is more disparate, less well-developed and poorly controlled.

\subsubsection{Preferred end-of-life options and circular practices for the automotive industry}

Social, economic, and environmental aspects in the development of an industrial ecology of the automotive sector have been widely discussed in the literature (Tukker and Cohen, 2004; Wells and Orsato, 2005). Likewise, the EoL management of the automotive sector has benefited from much academic research and industrial breakthroughs over the entire EoL value chain: collection and allocation (Chemineau, 2011; Simic, 2015), reuse, remanufacture of components, or recycling of materials (Reuter et al., 2006; Froelich et al., 2007; Millet et al. 2012; Indra, 2016), and dismantling (El Halabi et al., 2015; IDIS, 2016).

Diener and Tillman (2016) give a concise overview of current vehicle EoL management, showing that (i) component reuse (with or without remanufacturing) and materials recycling are prevalent in the automotive sector, (ii) such EoL management of vehicles leads to economic savings and environmental benefits, and (iii) integration of both new technologies, e.g. connected devices with numerous electrical components, and new materials to reduce vehicle weight are creating new challenges to EoL recycling; as a consequence, not only the integration of new technologies in recycling centres such as the Internet of Things (IOT) and connected devices (Yi and Park, 2015), but also recycling issues for new hybrid vehicles including lithium-ion batteries (Idjis et al., 2017) are now being studied.

In the case of Sweden, studied by Diener and Tillman (2016), an estimated 7\% of total cars out of use are exported or left to rust; $2 \%$ of cars out of use go directly to material handling facilities, where in line with Directive 2000/53/EC they are prepared for shredding, hazardous materials removal and depollution. The remaining cars ( $91 \%$ of cars out of use) go to dismantlers to recover components and materials for reuse and recycling.

Overall, EoL in the automotive sector, driven by EoL vehicle (ELV) regulations, described in sub-section 3.2., is increasingly controlled, organised and streamlined. Spare parts reuse and recycling of materials are the preferred EoL options and circular practices for the automotive industry. The ELV dismantling procedure is properly established and mastered by automotive recycling centres, as shown in Figure 1. Out of the 12 million vehicles taken off the roads in Europe each year (EMF, 2013a), 7-8 million tons of EoL vehicles are properly handled in Europe at authorised treatment facilities (ATFs) (EC, 2016b). According to experts from ADEME (French environmental agency) and INDRA (precursor and leading player in vehicle recycling in France), around $10 \%$ of vehicle mass is removed in a depollution phase (oils, fluids, chemicals, batteries, airbags), and another $10 \%$ of vehicle mass is removed on dismantling spare parts (outer and inner parts of high value or with a reuse potential, plus transmission system parts). This step is crucial, since the resale of spare parts is the main source of income for recycling companies (INDRA, 2016a). However, as automotive spare parts are less costly than HDOR ones, remanufacturing is often unprofitable and is therefore less welldeveloped for light vehicle components. The remaining $80 \%$ of vehicle mass is finally sent to shredder and smelting facilities to recycle materials so as to meet mandatory standards. 

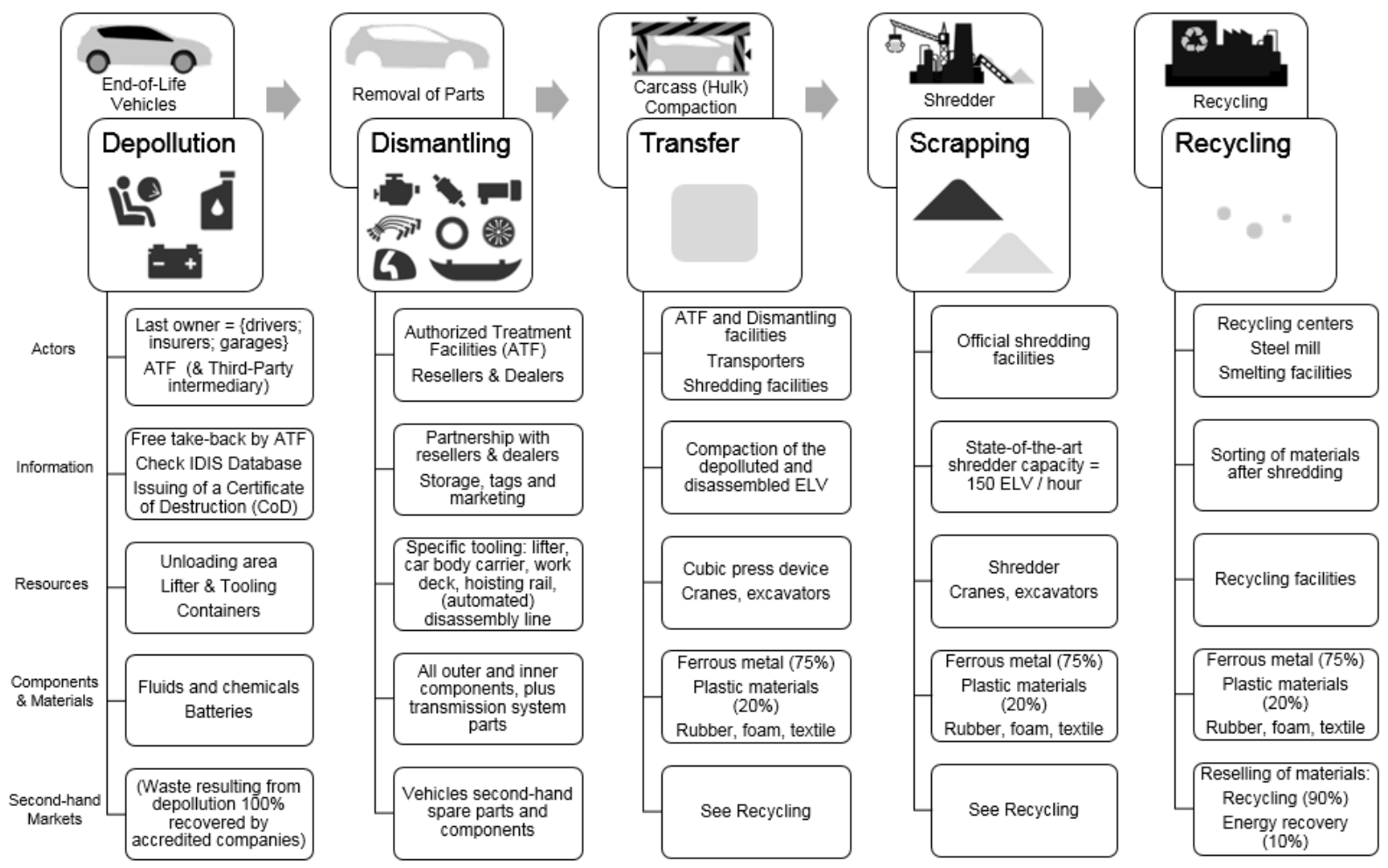

Figure 1 - End-of-life vehicle processing for the automotive sector, based on Toyota (2016) plus additional sources of information (INDRA, 2016a; Directive 2000/EC/53) and consulted experts

\subsubsection{Preferred end-of-life options and circular practices for the HDOR industry}

Dismantling and recycling of EoL HDOR vehicles is still a minority market outlet compared with resale and export. The export and resale of HDOR vehicles is currently commercially viable. However, this channel does not deal satisfactorily with the ultimate EoL of these heavy vehicles. According to the interviews carried out and knowledge gained in the 5-month internship, the environmental awareness of actors in this sector seems low. Furthermore, there are no specific EoL treatment facilities dedicated to heavy vehicles, unlike light vehicles (ADEME, 2006). Cetim (2014) performed a technological watch on the EoL and dismantling channels for heavy vehicles in France and in Europe (Western and Central Europe): some CE loops for HDOR vehicles, such as remanufacturing, refurbishing and reuse, are operating well, HDOR components being mainly refurbished by remanufacturing processes to give HDOR vehicles a second life. However, these overhauled HDOR vehicles are then exported to developing countries that do not have the means to dismantle and recycle heavy vehicles properly at the end of their lifespans.

The EoL management of HDOR vehicles is still a marginal and poorly structured activity in Europe. Recycling HDOR vehicles is often voluntary and not fostered by recycling targets or extended producer responsibility. To illustrate this point, according to the Center for Remanufacturing and Reuse (Walsh, 2013) in the UK, out of all heavy vehicles reaching their EoL, 50\% are reused or resold in other countries after major refurbishment, $43 \%$ are remanufactured to extend their lifespan in the UK, and $7 \%$ are dismantled and recycled in the UK. In Sweden, approximately $50 \%$ of trucks were estimated to be exported after 5 years of domestic use (Diener and Tillman, 2016). Likewise, according to a director of an NRMM rental company, brand new NRMM is usually resold after five years of use to an intermediary actor who exports it to Eastern Europe and North Africa. This is because clients prefer to rent HDOR vehicles in mint condition, and after five years in use the original manufacturer warranty has often expired.

Additionally, as reported by an expert at CIDER Engineering, the number of non-authorised infrastructures handling EoL HDOR vehicles is still too high. Moreover, even in the most developed European countries, current EoL treatment of HDOR is not satisfactory as regards safety, economic, environmental, and technical aspects. In this light, according to CIDER Engineering, true CE needs the optimisation of dismantling processes and the reintroduction on the market of not only components and spare parts, but also materials derived from a well-established recovery procedure. 
To cite this version: Michael Saidani, Bernard Yannou, Yann Leroy, François Cluzel, Heavy vehicles on the road towards the circular economy: Analysis and comparison with the automotive industry, Resources, Conservation and Recycling, 2017, ISSN 0921-3449, http://dx.doi.org/10.1016/j.resconrec.2017.06.017.

To explain the marked difference observed between the two sectors, we review key factors impacting their EoL management: regulations, market and business model evolution, and new and emerging technologies.

\subsection{IMPACTS OF EXISTING REGULATIONS}

End-of-life in the automotive sector is subject to a set of regulations. By contrast, to date there are no overall EoL regulations for the HDOR industries. HDOR vehicles are presently concerned only by cross-sector regulations, such as those for EoL tyres and oil depollution. A concise overview of the regulations related, directly or indirectly, to CE and applied to the automotive and HDOR sectors is given in Table 3.

Table 3 - Regulations applied to automotive and HDOR sectors and relevant to the circular economy

\begin{tabular}{|c|c|c|}
\hline Regulation type & Automotive sector & HDOR sector \\
\hline $\begin{array}{l}\text { End-of-life regulations (mandatory } \\
\text { recycling and/or recovery targets) }\end{array}$ & $\begin{array}{l}\text { Yes: Directive on ELV 2000/53/EC; } \\
\text { Directive } 2008 / 33 / E C \text { (amendment). }\end{array}$ & None \\
\hline Extended Producer Responsibility & Yes, included in the ELV Directive & None for the whole HDOR vehicle \\
\hline Emissions regulations & Euro $6 \mathrm{~b}$ for light vehicles & $\begin{array}{l}\text { Euro } 6 \text { for HDVs; Stage IV for } \\
\text { NRMM. }\end{array}$ \\
\hline $\begin{array}{l}\text { Cross-sector regulatory frameworks for } \\
\text { both automotive and HDOR vehicles } \\
\text { and components }\end{array}$ & \multicolumn{2}{|c|}{$\begin{array}{l}\text { Extended Producer Responsibility (EPR) for, tyres, oils, batteries and electrical } \\
\text { and electronic equipment (EEE); } \\
\text { Directive 2002/96/EC WEEE (Waste Electrical \& Electronic Equipment); } \\
\text { Regulation (EC) No 1907/2006 REACH (Registration, Evaluation, Authorisation } \\
\text { and Restriction of Chemicals); } \\
\text { Directive 2008/35/EC RoHS (Restriction of Hazardous Substances). }\end{array}$} \\
\hline $\begin{array}{l}\text { Additional, complementary or other } \\
\text { policy frameworks linked, directly or } \\
\text { indirectly, to the circular economy }\end{array}$ & $\begin{array}{l}\text { Directive 2005/64/EC (on the type- } \\
\text { approval of motor vehicles with regard } \\
\text { to their reusability, recyclability and } \\
\text { recoverability); } \\
\text { Directive 2002/151/EC (certification of } \\
\text { destruction for ELV handling); } \\
\text { Directive 2003/138/EC (components } \\
\text { and materials coding standard for } \\
\text { vehicles); } \\
\text { Directive 2005/293/EC (detailed rules } \\
\text { for monitoring compliance with the } \\
\text { ELV Directive targets). }\end{array}$ & None \\
\hline
\end{tabular}

In the automotive sector, European Directive 2000/53/EC aims to reduce waste from EoL vehicles. The scope of this directive is limited to passenger cars and light commercial vehicles up to nine seats and up to a total weight of 3.5 tons. The directive sets targets for reuse, recycling, and recovery. Since January 2015 , these have been a minimum $85 \%$ reuse and recycling rate and a minimum 95\% reuse and recovery rate for each vehicle. The directive includes Extended Producer Responsibility (EPR), which involves different actors and involves the following mechanisms:

- Free take-back of EoL vehicles (ELVs) and used tyres since January 2007;

- Producer obligation for providing not only take-back of ELVs through accessible networks of authorised treatment facilities (ATFs) and collection points, but also dismantling information for new vehicles within six months of their being placed on the market;

- Database for the automotive sector: International Dismantling Information System (IDIS);

- Public Responsibility: the registered owner of a vehicle who wants to discard it as waste is required to bring it to an ATF for appropriate treatment and recovery;

- Certificates of Destruction: since January 2007, when an EoL vehicle is deposited at an ATF, the operator of that facility shall issue a certificate of destruction to the registered owner.

Idjis et al. $(2013,2017)$ see this legislation as pushing for more cooperation between the actors of the automotive sector, such as original equipment manufacturers (OEMs), authorised treatment facilities, end users, and other EoL third parties. The effectiveness, relevance, strengths and weaknesses of the ELV Directive (2000/53/EC) have been discussed by the European 
To cite this version: Michael Saidani, Bernard Yannou, Yann Leroy, François Cluzel, Heavy vehicles on the road towards the circular economy: Analysis and comparison with the automotive industry, Resources, Conservation and Recycling, 2017, ISSN 0921-3449, http://dx.doi.org/10.1016/j.resconrec.2017.06.017.

Commission (EC, 2014b), and one conclusion drawn is that the various environmental and economic benefits of the ELV Directive outweigh the costs of its implementation: the costs of complying with the Directive are estimated by the industry to be significant, e.g. for car manufacturers to remove hazardous substances, or for recyclers to develop the technologies necessary to meet the targets, but they are outweighed by the profits gained from the sales of recycled parts. However, two major challenges remain. First, the collection and treatment of ELVs by illegal operators and the illegal shipment of ELVs are still flourishing businesses: increasing co-operation among European Union member states is therefore needed to ensure tracking and follow-up of de-registered and exported vehicles. Second, a new issue has appeared: the introduction of complex electronic systems and composite materials in modern vehicles poses significant technological challenges for maintaining the overall reuse, recycling, and recovery rates of ELVs. The ACEA (2015) likewise acknowledges that the ELV Directive has proven highly effective in reducing discard of waste from vehicles, increasing reuse, recycling and recovery, and ensuring that ELVs are treated in an environmentally sound way.

Meanwhile, in the HDOR sector, except for legal necessities such as REACH and RoHS, emissions regulations (Euro 6 in Europe for HDVs and Stage IV for NRMM) and cross-sector regulatory frameworks (EPR on tyres, oils and batteries), as detailed in Table 3, there are no regulations or directives that compel the HDOR industry to apply more sustainable management of vehicle EoL. In Europe, there are some 20 million HDOR vehicles in use that are not subject to overall EoL regulations (Weiland, 2014). According to an expert from ADEME (French environmental agency), although a possible extension of the ELV Directive (2000/53/EC) to EoL HDOR vehicles was mooted by Spanish representatives at the European Commission in Brussels in 2014, no new European legislation concerning HDOR vehicles is expected in the short term. In the absence of any regulation in the HDOR industry, the HDOR manufacturers are not asked to deal with the retired fleet. Motivation of manufacturers to participate in EoL HDOR projects, and in circular practices, has to be sought elsewhere, for example in the residual value of EoL HDOR vehicles, or in the reuse or recovery of key components and materials for second-hand products that require less primary raw materials extraction, energy, and labour.

Wilts et al. (2016) stress the importance of policy mixes, such as waste targets for resource efficiency and extended producer responsibility, in driving progress towards a more circular economy. The impact of recent CE policy initiatives in Europe, such as the "European Commission Circular Economy Package" $(E C, 2015)$ has not yet been evaluated. Nevertheless, the policies and targets in place do not directly concern the HDOR vehicle industry. Furthermore, the question of materials ownership and responsibility in CE also remains unanswered for many industrial sectors including the HDOR sector, and is therefore a key challenge in seeking insights on "how the loop will close and by whom?" (Velis and Vrancken, 2015).

\subsection{BUSINESS MODEL EVOLUTION: IMPACTS OF REMANUFACTURING AND PSS}

In the automotive and HDOR industries, new business models are emerging and will continue to flourish, favouring usage-based income opportunities, both for ownership and servicing of vehicles (IBM, 2009): evolution towards more circular businesses and processes could offer economic, environmental and social benefits through remanufacturing (Japke, 2009; Kwak and Kim, 2016) or product-service-system (PSS) practices (Bocken et al., 2015; Tukker, 2015). These business practices that seek to close the loops in the automotive and HDOR sectors are examined in this subsection.

Automotive vehicles in use far outnumber HDOR vehicles, at around 270 million against 20 million in the EU (ICCT, 2016). However, HDOR vehicles use more remanufactured components, and HDOR components are 4-5 times more expensive (Weiland, 2014). For light vehicles, standard components that are remanufactured are mainly starters and alternators, fuel injection parts, electronic control modules, transmissions, engines, gearboxes and turbochargers. For HDOR vehicles, further components are remanufactured, such as hydraulic pumps and cylinders, water and oil pumps, oil coolers, air compressors and actuators, radiators, retarders and particle filters, differentials and hydraulics, and tyres. HDOR component values and dimensions are also much higher: for instance, an average car transmission weighs $40 \mathrm{~kg}$, whereas an average HDOR transmission weighs $200 \mathrm{~kg}$. Overall, in Europe, the HDOR remanufacturing market is performing well, with 3.5 million remanufactured spare parts sold in 2013, corresponding to 3.7 billion euros in annual sales and 279,000 tons of annual $\mathrm{CO}_{2}$ savings. In comparison, the European automotive remanufacturing business is estimated to be worth 5.7 billion euros. As a relevant illustration, 
To cite this version: Michael Saidani, Bernard Yannou, Yann Leroy, François Cluzel, Heavy vehicles on the road towards the circular economy: Analysis and comparison with the automotive industry, Resources, Conservation and Recycling, 2017, ISSN 0921-3449, http://dx.doi.org/10.1016/j.resconrec.2017.06.017.

retreading HDOR tyres is one of the most successful HDOR remanufacturing practices. Unlike car tyres, which have a low value and are not worth retreading, the value of HDOR tyres for mining or construction applications is high and so such practices are attractive. The European market for HDOR tyres is vast, with a market share of retreaded and remanufactured HDOR tyres of 3.8 million units, corresponding to 1.1 billion euros in annual sales and a source of non-negligible environmental savings (285,000 tons of annual $\mathrm{CO}_{2}$ saved) (Weiland, 2014). The remanufacturing market for HDOR vehicles was also recently analysed by the European Commission and the European Remanufacturing Network (EC and ERN, 2015). Globally, the HDOR sector is currently worth 122 billion euros to the European economy, which includes new manufacturing and repair of HDOR equipment. More specifically, the European remanufacturing market was estimated to be worth 4.1 billion euros in 2014, consistent with the figure of 3.7 billion euros in 2013, as stated above. Germany is estimated to account for $27 \%$ of the market, France, Italy and UK representing $15 \%, 13 \%$ and $12 \%$ respectively. The sector is estimated to employ 20,000 people in more than 500 firms in Europe (EC and ERN, 2015).

However, some issues still have to be tackled to reach the full potential of the HDOR remanufacturing market. HDOR spare parts handling and processing are very heterogeneous. Some components are well-suited to profitable remanufacturing (e.g. tyres, alternators and starters account for $70 \%$ of the remanufactured market), but others are directly replaced by brand-new parts (e.g. catalytic converters and pneumatic brakes account for $75 \%$ of the brand-new market) (Weiland, 2014). Additionally, the requirement to keep large inventories of remanufactured components to cover all the potential parts that may need replacing is a prohibitive obstacle, and only attempted by the largest OEMs (e.g. Caterpillar and JCB). A few smaller businesses indicated that they felt they were too small to get involved in remanufacturing activities, and it would not be cost-effective for them to embark on such activities. On the other hand, the aftersales market, previously managed and handled by thirdparty companies and intermediaries, is now becoming a key challenge for OEMs, competing with independent firms.

Compared with the automotive sector, the remanufacturing market for HDOR stands out by some specific features: not only is it already a sizeable business area, but it can also claim a greater growth potential than any other industrial sector, according to the CRR Institute in the UK (Walsh, 2013) (Chapman et al., 2010). NRMM rental, for instance, is still a growing market that has not yet reached its full potential (Cetim, 2014). As a result of the acceleration of technological innovation and the increasing complexity of equipment, the construction sector is also characterised by a rising demand related to continuous maintenance services for equipment leased on a 24/7 basis. Teams, infrastructures and organisations capable of repairing or replacing failing equipment using remanufactured products are increasingly active (Cetim, 2014). Major manufacturer companies such as Caterpillar are well aware of the current trend in business model evolution: "before, core business was manufacturing, soon it could be remanufacturing" (Snodgress, 2012).

In Europe, the remanufacturing market for HDOR parts is therefore large, competitive and very dynamic, with great promise of growth. Manufacturers have identified this growing market, creating special services and channels of remanufactured products for their clients. Rental companies are also increasingly entering this market, while also starting to compete with original equipment manufacturers to extend the operational lifespan of their heavy vehicles (Cetim, 2014). While remanufacturing activities are still alive throughout the EU, the increased availability of inexpensive new aftermarket parts from Asia has reportedly made it difficult for remanufacturers in Western Europe to remain competitive (USITC, 2012).

Lastly, Diener et al. (2015) set out to determine whether product-service-system (PSS) was really a relevant solution for materials efficiency in the HDOR sector. In their study, the following questions were addressed: "what would the company do differently if they were to sell truck function and retain truck function throughout the truck's lifecycle?" and "how would changes made by the companies affect the materials use required to deliver truck function?". To assess the potential effects and benefits of PSS on materials efficiency, three HDOR components made mainly of steel were considered (engine, gearbox, and wheel-end). Experiments on Business Model Canvas (BMC) and Material Flow Analysis (MFA) comparing current state and modified PSS-state concluded on a benefit of $23 \%$ for materials efficiency for the latter. However, while organisational capabilities (networks and resources) were considered in this study, financial aspects (cost structure and revenue streams) and possible exportations to less developed countries lie outside its scope. 
To cite this version: Michael Saidani, Bernard Yannou, Yann Leroy, François Cluzel, Heavy vehicles on the road towards the circular economy: Analysis and comparison with the automotive industry, Resources, Conservation and Recycling, 2017, ISSN 0921-3449, http://dx.doi.org/10.1016/j.resconrec.2017.06.017.

\subsection{INTEGRATION OF EMERGING AND PROMISING TECHNOLOGIES: CHALLENGES AND NEW OPPORTUNITIES}

New and emerging technologies integrated in automotive and HDOR vehicles, such as telematics, Internet of things (IOT) and connected devices, should be intelligently used as enablers. They could be deployed as a means to an end, rather than as an end in itself, for industrial operators to manage their automotive or HDOR vehicles and components throughout their life cycles, and thereby run more competitive and greener businesses (Walker and Manson, 2014; Husnjak et al., 2015; Gnimpieba, 2015). Telematics systems are automobile systems that combine wireless communications for automatic roadside assistance and remote diagnostics. A review of available telematics systems offering an analysis of the usefulness of each telematics solution was made by the NSTSCE (2012). The contributions of telematics during the use phase, e.g. fuel savings, have been widely studied and are beyond the scope of the present paper. To give an example, a case study on real benefits of telematics has shown that telematics can be used to monitor and improve safe driving behaviour as well as monitor and improve fuel economy in trucks (USDoT, 2014). Importantly, the question of the potential contributions of new and emerging technologies as a support in the move towards CE in the automotive and HDOR industries, is becoming increasingly significant: telematics and associated connected devices could certainly facilitate and foster new and closer relationships between suppliers, service providers and users, through customised insurance, take-back offers, technical warnings, and preventive maintenance (NSTSCE, 2012). Also, thanks to the tracking and monitoring of transportation systems with the loT, enhanced control of illegal exports will be possible. According to IBM (2009), telematics will be an indispensable part of tomorrow's heavy vehicles. Whereas today's vehicle diagnostic techniques typically require the technician to physically connect to the vehicle, the future capabilities of telematics will enable remote vehicle diagnostics.

Additionally, loT sensors add intelligence to automotive and HDOR vehicles as hundreds of sensors fitted on vehicles such as commercial trucks generate large volumes of real-time data. The current challenge is to translate the data thus obtained into meaningful information that optimises, for instance, vehicle usage or maintenance (Intel, 2015). Some ongoing research and studies are ready to go further, capturing real-time performance, user activities and feedback from the field, not only for the purpose of real-time usage optimisation, but also to improve the future design of vehicles and machinery considering their entire life cycle (Ma et al., 2014). However, only a small proportion of automotive HDOR vehicles are currently equipped and monitored with such advanced telematics systems: a survey performed in 2014 by the Association of Equipment Manufacturers found that $62 \%$ of US construction companies had no plans to implement telematics anytime soon. Also, according to a director manager from an NRMM rental company, such technologies are not seen as really useful for small machinery users, but only for major construction sites with large fleets of heavy machinery working together. Another challenge is to link these telematics and connected devices with business models facilitating the EoL management, (prolong, maintain, reuse, remanufacture, recycle), of automotive and HDOR vehicles. Among innovative business models interlinking leasing services and connected devices, a geo-tracking online platform allowing HDOR equipment, and particularly NRMM, to be localised, that is available in a chosen area at both end of usage and EoL is increasingly used by civil engineering companies (Matexchange, 2016). As advocated by a road construction site supervisor from Colas, who has used NRMM since 1979 and has therefore noted some evolution, it would be useful to have more information about the wear and tear of components through the use of such connected devices in order to prevent component breakdown and forecast more accurate preventive maintenance, and thereby contribute to the circular economy in practice.

\subsection{INDUSTRIAL PRACTICES, INITIATIVES AND INCENTIVES TO CLOSE THE LOOPS}

To illustrate the previous sub-sections with concrete examples from the industrial field, we now make an in-depth analysis of best industrial practices in the automotive and HDOR sectors to close the loop. The practices of major NRMM constructors in progress towards CE were analysed: Liebherr (DE ownership), Caterpillar (US), John Deere (US), Volvo Construction Equipment (SE), and Manitou (FR). Likewise, remanufacturing programmes and innovative commercial offers of five main HDV constructors were analysed to gain relevant insights and identify best initiatives in a CE perspective (Volvo Truck (SE), Scania (SE), MAN (DE), DAF (NL) and Daimler Trucks North America (US)). For the automotive sector, the example of French major constructor Renault was taken to illustrate best automotive practices on the road to CE. In the NRMM sector, although Caterpillar has 
To cite this version: Michael Saidani, Bernard Yannou, Yann Leroy, François Cluzel, Heavy vehicles on the road towards the circular economy: Analysis and comparison with the automotive industry, Resources, Conservation and Recycling, 2017, ISSN 0921-3449, http://dx.doi.org/10.1016/j.resconrec.2017.06.017.

the most extended and developed remanufacturing program and offer, several commercial offers related to aftersales services from main NRMM constructors are also discussed. In the HDV sector, the example of Volvo Truck lends significant insights into the EoL stage and new business offers.

\subsubsection{Insights from automotive operators}

Renault was chosen by the Ellen MacArthur Foundation to illustrate CE in the automotive industry (EMF, 2013a). In 2012, Renault's Choisy-le-Roi plant remanufactured around 200,000 components of six types of mechanism, such as gearboxes and injectors. In this remanufacturing centre, the savings from producing a remanufactured part compared with a new part are $80 \%$ less energy, $88 \%$ less water, and $92 \%$ less chemicals. In terms of raw materials, the Choisy-le-Roi factory does not send any waste to landfill: $43 \%$ of a carcass is re-usable ( $72 \%$ of the mass of a gearbox and $37 \%$ of the mass of an engine); $48 \%$ is recycled in the company's foundries to produce new parts, and the remaining $9 \%$ is valorised in processing centres, meaning the entire recovery process is waste-free. Additionally, Renault has built a network for the efficient, profitable EoL treatment of vehicles, which includes INDRA (a pioneer in automotive recycling) and Suez Environment (a specialist in global waste management and recycling).

More specifically, the INDRA network activities help disseminate best practices among EoL treatment facilities regarding management, depollution, dismantling and recycling of ELVs (INDRA, 2016a). INDRA also "provides ELV centres with a dedicated software suite, designed to meet their every need and guarantee traceability throughout the chain, from the administrative management of vehicles to evaluating demand, dismantling, and the technical identification of reusable parts intended for resale" (INDRA, 2016b). This recent advance helps fill a gap noted by Despeisse et al. (2015), who examined the circularity of EoL vehicles in the UK and Japan. A clear lack of an information system to support the EoL management in a centralised way was observed. They report that data collected and available were still insufficient to understand and decide on the best fate of components and materials. Since this study was completed, progress has been made in these areas: the complete handling of ELVs is becoming an increasingly efficient industrialised procedure. For instance, the entire dismantling time has been optimised to 3 hours per vehicle, and state-of-the-art ELV centres can ensure the complete disassembly of 25 vehicles per day.

Overall, by prolonging and maintaining the lifespan of the vehicles by parts remanufacturing, the factory in Choisy has created a comprehensive circular model. Moreover, this activity complies closely with the principles of the three pillars of sustainability. First, socially, it involves a skilled workforce and creates jobs locally (325 employees are working on the site). To be economically viable (turnover of 100 million euros), remanufacturing has to be performed within the market region in which the vehicles are used. Though 30-50\% less expensive, the remanufactured parts have the same guarantee, and are subject to the same quality control tests as new parts. Lastly, environmentally, it retains added value of components and saves energy, while reducing waste, as detailed above.

Additionally, in the automotive sector, research projects and investigations also focus on mechanisms to improve recycling and recovery rates during early design and development phases, and thereby the circularity of vehicle components or materials. Garcia et al. (2015) propose a tool for evaluating the impact of innovation on the EoL pathway of a vehicle. The goal of this tool, called OSIRIS (Simulation Tool of the Impact on Recyclability of Innovations), developed in collaboration with the French automotive manufacturer PSA, is to help the engineers of the innovation department evaluate the impact of their innovations on a vehicle's recyclability and recoverability rates.

\subsubsection{Insights from HDV sector practitioners}

In terms of design and during product development, the Volvo Group (2015) meets major prerequisites to fit CE principles: Volvo's trucks are largely recyclable, almost $85 \%$ of their weight consisting of metal, mostly iron, steel and aluminium. The additional materials are mainly plastic, rubber and materials from electronic components. Today, approximately one third of a Volvo Group truck is produced from recycled materials, and $80 \%$ of the engine can be reused. The Volvo Group has developed manuals and other tools to assist disassembly workers in extracting the most from used vehicles. For instance, the dismantling manual (Volvo Truck Corporation, 2012) provides practical and illustrated recommendations about the possible handling, reuse or recycling of chemicals and fluids (oil, AdBlue, solvents, coolant, brake fluid, refrigerant, glycol, glue, washer fluid, sulphuric acid) and other components and materials (batteries, air bags, belt tensioners, oil filters, laminated 
To cite this version: Michael Saidani, Bernard Yannou, Yann Leroy, François Cluzel, Heavy vehicles on the road towards the circular economy: Analysis and comparison with the automotive industry, Resources, Conservation and Recycling, 2017, ISSN 0921-3449, http://dx.doi.org/10.1016/j.resconrec.2017.06.017.

glass, silencer, electrical and electronic waste, lamps and tubes, switches, gas discharge lamps, brake discs, rubber).

When a Volvo FH Globetrotter is properly dismantled, i.e. $95 \%$ of its weight (approximately $7,000 \mathrm{~kg}$ ), the total resale of spare parts can reach 40,000 euros. According to an environmental manager at Volvo Truck Recycling, the EoL processing of a truck is much more complex, energy and labour-intensive, as well as less well developed than in the automotive sector. In a Volvo dismantling plant, EoL processing comprises cleaning and depollution (i.e. batteries and fluids removal), undressing (i.e. headlights, sheet metal bodywork, and cabin removal), dismounting (all components to access the engine) and butchering (axles, chassis, wheels). It also requires two expert garage mechanics working for three days in a workshop with specific tools.

The remanufacturing market share of Volvo is also expanding, a good indicator of the move towards CE. In 2015, the total sales of remanufactured components amounted to 0.83 billion euros, an increase of almost $20 \%$ over 2014. Remanufactured components reduce customers' ownership and operating costs (Volvo Group, 2015). Volvo is also one of the most mature companies for telematics integration in their HDOR fleet. In 2015, approximately 470,000 Volvo Group vehicles were connected via different telematics solutions, including services such as Volvo Dynafleet, Renault OptiFleet, UD Telematics and the Volvo CE CareTrack, in a fleet of more than two million trucks.

Regarding circular product design practices, many of the Volvo Group's products have a common architecture and shared technology (CAST) based on a modularised concept and standard interfaces. The Volvo Group's heavy-duty and medium-duty engine platforms are at the centre of the CAST strategy, as illustrated in Figure 2. There is also a high degree of commonality in electronics and transmissions. This modular product design (MPD) approach makes remanufacturing and reuse of spare parts easier, and thereby contributes to the shift towards CE. Furthermore, according to $\mathrm{Ma}$ and Okudan Kremer (2014), adopting a systematic MPD strategy leads to benefits in terms of the three pillars of sustainability.

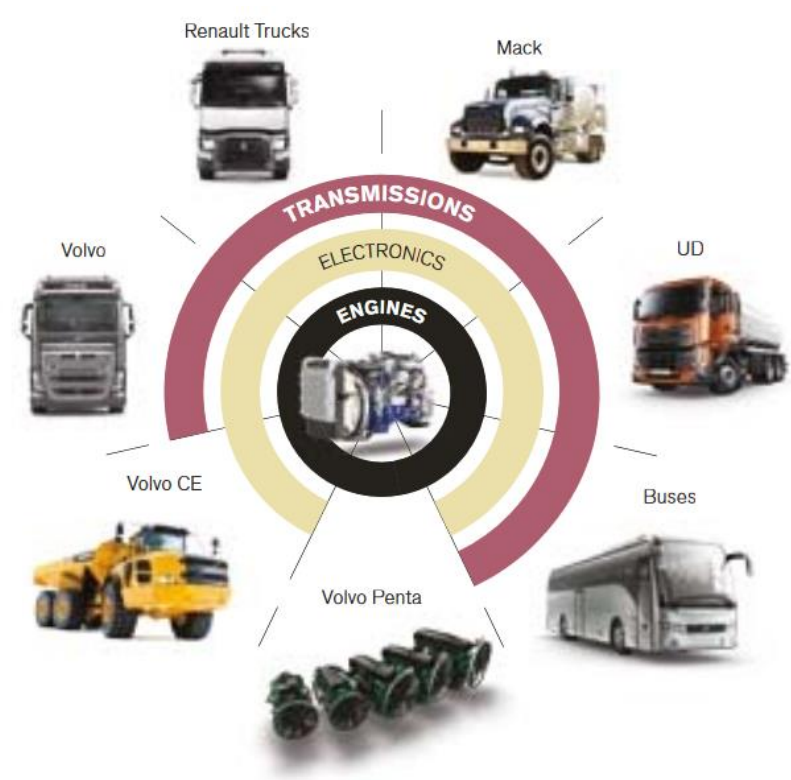

Figure 2 - Volvo Common Architecture and Shared Technology (CAST) to facilitate component reuse, and contribute to the circular economy of spare parts. Excerpt from Volvo Group (2015)

Another industrial example that illustrates the transition of HDVs towards CE is the DAF Company. DAF has already anticipated a possible extension of the European Directive related to ELV $(2000 / 53 / E C)$. More than $93 \%$ of all the materials in a standard DAF truck can now be reused. For example, the plastic parts of a DAF truck can easily be separated during dismantling. Like Volvo, DAF provides special sorting guides for each truck type. Also, DAF is proactive in the remanufacturing and reuse of components. In DAF's overhaul workshop in Eindhoven, an annual total of more than 50,000 parts are overhauled and supplied for reuse. These parts include starter motors, fuel pumps, gearboxes and even complete engines. These exchange parts are of a similar quality to new parts, and the same guarantee is provided for both. 
To cite this version: Michael Saidani, Bernard Yannou, Yann Leroy, François Cluzel, Heavy vehicles on the road towards the circular economy: Analysis and comparison with the automotive industry, Resources, Conservation and Recycling, 2017, ISSN 0921-3449, http://dx.doi.org/10.1016/j.resconrec.2017.06.017.

\subsubsection{Insights from NRMM sector practitioners}

Caterpillar is a renowned model of an off-road equipment company embracing CE through remanufacturing; it ended runner-up among The Circulars 2016 Finalists. Caterpillar has incorporated CE principles across its value chain, including product development, supply chain, dealer network, and customer relationships. Caterpillar's remanufacturing activity began in 1973, and has since grown to encompass 17 facilities worldwide, employing over 4,100 people dedicated to remanufacturing activities in a business model with an emphasis on component recovery. In 2012 Caterpillar's remanufacturing programme took back over 2.2 million EoL units for remanufacturing, representing 73,000 tons of materials, and including 6,000 different remanufactured products. Incentives such as a deposit scheme and voluntary take-back of products ensure that large quantities of parts are returned to Caterpillar, as shown in Figure 3. Caterpillar has a global network of remanufacturing hubs in which the returned products are remediated; in Europe the following sites undertake remanufacturing activities: Chaumont in France; Bazzano, Castelvetro, Frosinone, and San Eusebio in Italy, Radom in Poland; and Shrewsbury and Skinningrove in the UK. Another success factor for Caterpillar's remanufacturing program is that the company considers the entire product life cycle during the design phase, taking into account types of materials used and ease of disassembly for repair, remanufacture, reuse or recycling. The company also implements digital technology to drive circular transformation via its remanufacturing. One example is the telematics platform "Caterpillar Product Link", which provides information about the location, utilisation and condition of any given equipment, which facilitates remanufacturing processing. Lastly, Caterpillar is also finding ways to expand its remanufacturing business model to help address growing environmental concerns, such as the electronics waste increasingly left by HDOR equipment (Snodgress, 2012). All in all, the company's circular economy portfolio generated almost 10 billion euros in 2014 , accounting for $18 \%$ of the company's total sales and revenues.

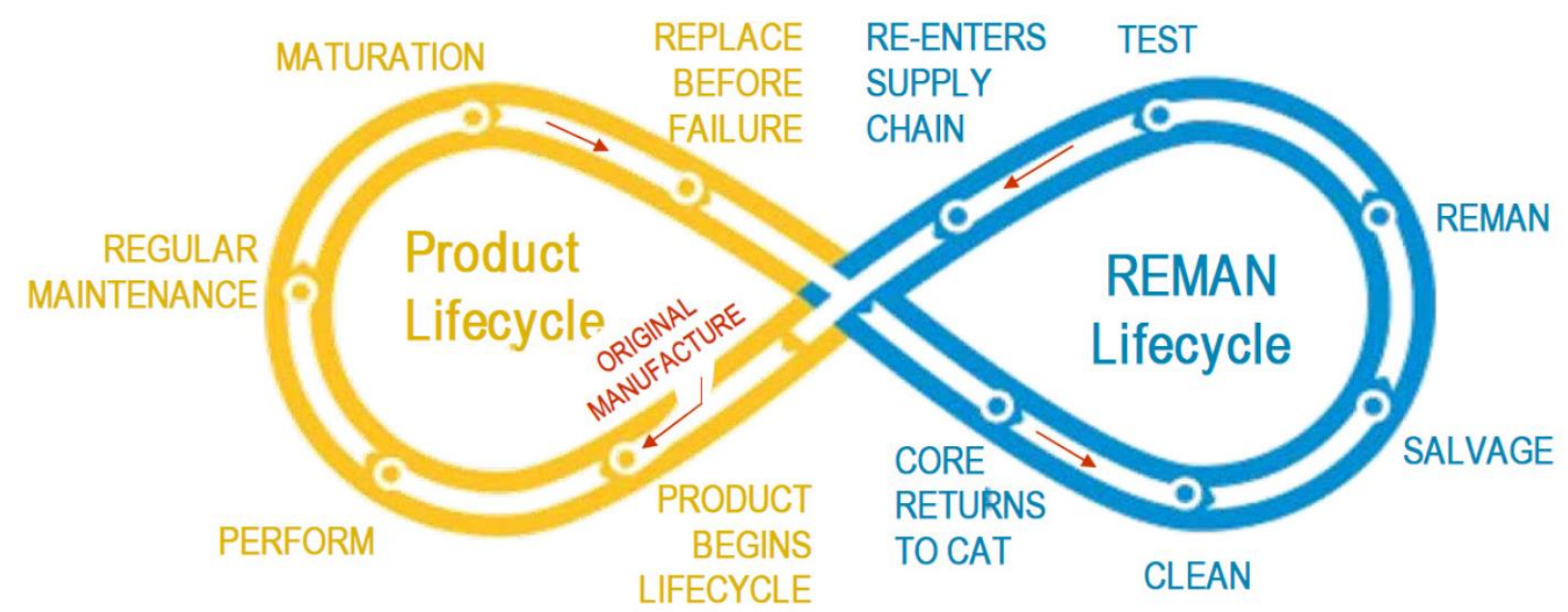

Figure 3 - Caterpillar's REMAN value chain to close the loop, excerpt from Snodgress (2012)

Recently more and more other companies have been developing their remanufacturing offers in order to stay competitive. For instance, Liebherr has been extending its remanufacturing programme since 2004 at its Ettlingen site in Germany, offering three remanufacturing options for a range of components: exchange, general overhaul or repair. Concerning emerging technologies and connected devices for HDOR equipment, the telematics platform LiDAT, designed and developed by Liebherr, includes maintenance management with services such as an automatic reminder of routine maintenance (e.g. gearbox oil changes or maintenance on brakes) or date planning for acceptance procedures (e.g. expert inspections). Fostering preventive maintenance is thus one good step towards maintaining and prolonging the lifespan of NRMM, and so contributes positively to CE. Similarly, John Deere's JDLink telematic offer allows owners and fleet managers to monitor equipment remotely: the JDLink telematics system includes location tracking, remote diagnosis and repair sessions for a better traceability and usage of the machine throughout its life cycle.

Taking into account the different legislations for automotive and HDOR sectors, it is noteworthy that Renault offers an example of practices commonly applied by other car manufacturers in the EU, 
To cite this version: Michael Saidani, Bernard Yannou, Yann Leroy, François Cluzel, Heavy vehicles on the road towards the circular economy: Analysis and comparison with the automotive industry, Resources, Conservation and Recycling, 2017, ISSN 0921-3449, http://dx.doi.org/10.1016/j.resconrec.2017.06.017.

such as the German Volkswagen Group, whereas the approaches of Volvo, DAF and Caterpillar are not followed by their competitors in the HDOR sector. Possible transfer of best practices from light vehicles to heavy ones, and vice versa, are analysed in the next sub-section through the lens of the circular economy.

\subsection{BEST PRACTICES AND REMAINING CHALLENGES IN A CE PERSPECTIVE}

The situation of automotive and HDOR sectors on the road towards CE are compared and summarised in Table 4 in terms of the four CE building blocks, and in Table 5 for the four generic loops of the CE model defined by the EMF (2013b). Best practices (BP) and remaining challenges (C) are indicated as relevant. 
To cite this version: Michael Saidani, Bernard Yannou, Yann Leroy, François Cluzel, Heavy vehicles on the road towards the circular economy: Analysis and comparison with the automotive industry, Resources, Conservation and Recycling, 2017, ISSN 0921-3449, http://dx.doi.org/10.1016/j.resconrec.2017.06.017.

Table 4 - Best practices (BP) and challenges (C) in both sectors in terms of the CE building blocks

\begin{tabular}{|c|c|c|c|}
\hline $\begin{array}{l}\text { Building } \\
\text { blocks of CE }\end{array}$ & $\begin{array}{l}\text { Description } \\
\text { (EMF, 2013b) }\end{array}$ & Automotive sector & HDOR sector \\
\hline $\begin{array}{l}\text { Circular } \\
\text { Design } \\
\text { Product }\end{array}$ & $\begin{array}{l}\text { Product design } \\
\text { that facilitates } \\
\text { the reuse, } \\
\text { remanufacturing } \\
\text {, recycling and } \\
\text { recovery of } \\
\text { components } \\
\text { and materials. }\end{array}$ & $\begin{array}{ll}\text { BP: } & \\
\text { - } & \text { Eco-design practices, tools and } \\
\text { environmental requirements are } \\
\text { increasingly integrated within the } \\
\text { C: } \\
\text { design and development processes. } \\
\\
\text { improve performance during the use } \\
\text { phase (e.g. making vehicles lighter } \\
\text { often requires replacing steel with } \\
\text { lighter materials, such as aluminium, } \\
\text { polymers, composites or carbon } \\
\text { fibres) and design for recycling. } \\
\text { Integration of electronic systems } \\
\text { leads to new challenging issues for } \\
\text { reuse in another vehicle, operator- } \\
\text { friendly remanufacturing or recycling. }\end{array}$ & $\begin{array}{l}\text { BP: } \\
\text { Volvo's trucks are highly recyclable: } \\
\text { 85\% of their weight consists of iron, } \\
\text { steel and aluminium. One third of a } \\
\text { Volvo Group's truck is produced from } \\
\text { recycled materials. } \\
\text { - } \quad \text { Modular product design: the high } \\
\text { degree of commonality of Volvo } \\
\text { Group's products facilitates the } \\
\text { remanufacturing and reuse of spare } \\
\text { parts. } \\
\text { C: } \\
\text { - Complex components (multi-material } \\
\text { plus small electronical parts) are } \\
\text { often impossible to dismantle without } \\
\text { damaging them and are less re- } \\
\text { usable. }\end{array}$ \\
\hline $\begin{array}{l}\mathrm{Ne} \\
\mathrm{Bu} \\
\mathrm{Mo}\end{array}$ & $\begin{array}{l}\text { Innovative } \\
\text { business } \\
\text { models (BM) } \\
\text { that enable } \\
\text { circular value } \\
\text { chain, foster } \\
\text { exchanges and } \\
\text { products loops. }\end{array}$ & $\begin{array}{l}\text { BP: } \\
\text { beoperation and shared information } \\
\text { manufacturers to second-hand } \\
\text { dealers through authorised treatment } \\
\text { facilities - to meet the ELV Directive } \\
\text { and make profits from the EoL } \\
\text { management of cars. } \\
\text { C: } \\
\text { Used parts market in the EU is still } \\
\text { small compared with used parts } \\
\text { markets in Middle East, Asia and } \\
\text { North Africa. }\end{array}$ & $\begin{array}{ll}\text { BP: } & \\
\text { - } & \text { OEMs creating special services and } \\
\text { remanufactured offers for their } \\
\text { clients: continuous maintenance } \\
\text { services for leased equipment on a } \\
\text { 24/7 basis. } \\
\text { Innovative BM interlinking leasing } \\
\text { services and connected devices: a } \\
\text { geo-tracking online platform allowing } \\
\text { localisation of HDOR equipment. } \\
\text { - Caterpillar's take-back programme } \\
\text { including a deposit scheme and } \\
\text { voluntary take-back of products. } \\
\text { C: } \quad \text { Initial investments required to launch } \\
\text { circular practices are non-negligible. } \\
\text { - Increased availability of less } \\
\text { expensive aftermarket parts from } \\
\text { Asia. }\end{array}$ \\
\hline & $\begin{array}{l}\text { Reverse } \\
\text { logistics } \\
\text { recovering } \\
\text { products back } \\
\text { from users into } \\
\text { the supply } \\
\text { chain. }\end{array}$ & 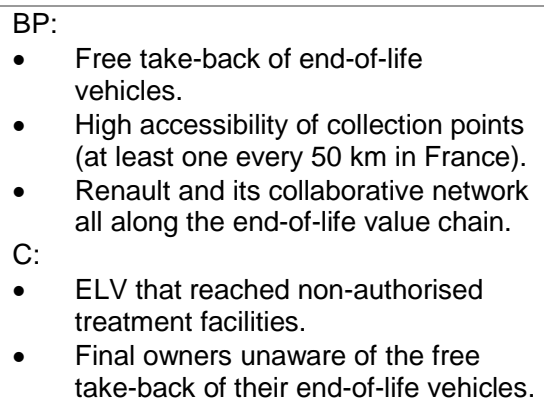 & $\begin{array}{l}\text { BP: } \\
\text { Emergence of telematic systems and } \\
\text { connected devices to foster the } \\
\text { tracking of HDOR fleet. } \\
\text { C: } \\
\text { - Lack of transparency of the end-of- } \\
\text { life value chain due to the significant } \\
\text { number of subcontractors and } \\
\text { intermediary third parties. } \\
\text { The question of who will own, fund } \\
\text { and be responsible for infrastructures } \\
\text { for reverse cycles is unclear. }\end{array}$ \\
\hline $\begin{array}{l}\text { Enak } \\
\text { Favo } \\
\text { Syst } \\
\text { Cond }\end{array}$ & $\begin{array}{l}\text { A number of } \\
\text { system } \\
\text { conditions that } \\
\text { can help } \\
\text { businesses } \\
\text { make the } \\
\text { transition, such } \\
\text { as education, } \\
\text { policies, } \\
\text { collaborations } \\
\text { and market } \\
\text { mechanisms. }\end{array}$ & $\begin{array}{l}\text { BP: } \\
\text { - Large numbers of HDOR units in } \\
\text { circulation: } 270 \text { million in the EU. } \\
\text { End-of-life vehicles Directive } \\
\text { (2000/53/EC) with mandatory levels } \\
\text { of reuse, recovery and recycling. } \\
\text { - Sweden, an example where } 91 \% \text { of } \\
\text { cars out of use are taken to } \\
\text { dismantlers. } \\
\text { C: } \quad \text { Time period between pre-life and } \\
\text { end-of-life: } 17.5 \text { years for cars. } \\
\text { Meanwhile, technologies and } \\
\text { materials used evolve. } \\
\text { Around } 4 \text { million European ELV are } \\
\text { still handled by non-authorised or } \\
\text { illegal treatment facilities: in France, } \\
1.1 \text { million ELV are properly handled } \\
\text { by ATF out of } 1.8 \text { million ELV } \\
\text { generated each year: loss of } 700.000 \\
\text { ELV in illegal treatment facilities. }\end{array}$ & $\begin{array}{l}\text { BP: } \\
\text { - Large numbers of HDOR units in } \\
\text { circulation: } 20 \text { million in the EU. } \\
\text { - High residual value of components } \\
\text { and materials included in EoL HDOR } \\
\text { vehicles. } \\
\text { Enhanced fleet management location } \\
\text { tracking, remote diagnosis and repair } \\
\text { sessions aiming at a better } \\
\text { traceability throughout the life cycle. } \\
\text { - } 470,000 \text { Volvo Group vehicles are } \\
\text { connected via different telematics } \\
\text { devices in a fleet of more than two } \\
\text { millions trucks. } \\
\text { C: } \\
\text { - Time period between pre-life and } \\
\text { end-of-life: around } 20 \text { years for } \\
\text { HDOR vehicles. Meanwhile, }\end{array}$ \\
\hline
\end{tabular}


To cite this version: Michael Saidani, Bernard Yannou, Yann Leroy, François Cluzel, Heavy vehicles on the road towards the circular economy: Analysis and comparison with the automotive industry, Resources, Conservation and Recycling, 2017, ISSN 0921-3449, http://dx.doi.org/10.1016/j.resconrec.2017.06.017.

\begin{tabular}{|l|l|l|}
\hline & $\begin{array}{l}\text { technologies and materials used are } \\
\text { evolving. } \\
\text { No end-of-life regulations for HDOR } \\
\text { vehicles, nor extended producer } \\
\text { responsibilities. } \\
\text { Current mind-set of HDOR actors } \\
\text { and users. }\end{array}$ \\
\hline
\end{tabular}

Table 5 - Best practices (BP) and challenges (C) in both sectors to close the loops

\begin{tabular}{|c|c|c|c|}
\hline $\begin{array}{l}\text { Feedback } \\
\text { loops of CE }\end{array}$ & $\begin{array}{l}\text { Description } \\
\text { (EMF, 2013b) }\end{array}$ & Automotive sector & HDOR sector \\
\hline $\begin{array}{l}\text { Maintain } \\
\text { Prolong }\end{array}$ & $\begin{array}{l}\text { The goal is to } \\
\text { keep artefacts } \\
\text { in circulation as } \\
\text { long as } \\
\text { possible, with } \\
\text { as high a value } \\
\text { as possible. } \\
\text { Design for } \\
\text { service and } \\
\text { maintenance. } \\
\text { From (end) user } \\
\text { to (new) user } \\
\text { (sometimes a } \\
\text { third party can } \\
\text { also intervene) }\end{array}$ & $\begin{array}{l}\text { BP: } \\
\text { Extension of the lifetime of the } \\
\text { vehicle economically viable thanks to } \\
\text { the remanufacturing of spare parts: } \\
\text { example of Renault and its } \\
\text { remanufacturing plant. } \\
\text { C: } \\
\text { Environmental and economic trade- } \\
\text { offs between extending the lifespan } \\
\text { of old vehicles and introducing brand } \\
\text { new vehicles, which pollute less } \\
\text { during the use phase. }\end{array}$ & $\begin{array}{ll}\text { BP: } & \text { Capturing real-time performance and } \\
\text { users' activities from the industrial } \\
\text { level to improve future design and } \\
\text { machinery considering whole life } \\
\text { cycle. }\end{array}$ \\
\hline $\begin{array}{l}\text { Reu } \\
\text { Red }\end{array}$ & $\begin{array}{l}\text { Design for } \\
\text { reuse and } \\
\text { optimisation of } \\
\text { second-hand } \\
\text { market to avoid } \\
\text { value loss. } \\
\text { From end-user } \\
\text { to service } \\
\text { providers. }\end{array}$ & $\begin{array}{l}\text { BP: } \\
\text { - Well-established dismantling system } \\
\text { is a viable source of second-hand } \\
\text { parts to the automotive aftermarket. } \\
\text { - Around } 60 \% \text { of car spare parts are } \\
\text { reusable at the end of car's lifetime. } \\
\text { - Feedback information about current } \\
\text { stocks and market demand provided } \\
\text { to state-of-the-art recycling centre. } \\
\text { - Computer software specialising in } \\
\text { monitoring second-hand spare parts } \\
\text { C: } \quad \text { and their dismantling for resale. } \\
\text { - }\end{array}$ & $\begin{array}{l}\text { BP: } \\
\text { - In the UK, } 50 \% \text { of all heavy vehicles } \\
\text { reaching their end-of-life are reused } \\
\text { or resold in other countries with } \\
\text { major refurbishment; } 43 \% \text { are } \\
\text { remanufactured to extend their } \\
\text { lifespan in the UK. } \\
\text { Redistribution of second-hand } \\
\text { components is a profitable business: } \\
\text { e.g. when a Volvo FH Globetrotter is } \\
\text { dismantled properly ( } 95 \% \text { of its } \\
\text { weight, i.e. } 7,000 \mathrm{~kg} \text { ), the overall } \\
\text { resale of spare parts can reach } \\
\text { C: } \\
\text { - Numeon euros. } \\
\text { quantity and location of end-of-life } \\
\text { HDOR vehicles, and about the } \\
\text { quality and conditions of used spare } \\
\text { parts. }\end{array}$ \\
\hline & $\begin{array}{l}\text { Returning a } \\
\text { product to its } \\
\text { original } \\
\text { performance } \\
\text { with a warranty. } \\
\text { Process that } \\
\text { makes } \\
\text { extensive reuse } \\
\text { possible. } \\
\text { From end-user } \\
\text { to manufacturer } \\
\text { factories or } \\
\text { remanufacturing } \\
\text { centres. }\end{array}$ & $\begin{array}{ll}\text { BP: } & \\
\text { - } & \text { Renault's Choisy-le-Roi } \\
& \text { remanufacturing centre with its } \\
& \text { associated collaborative and reverse } \\
\text { C: } & \text { supply chain network. } \\
\text { - } & \text { Limited number of remanufactured } \\
& \text { spare parts from light vehicles. }\end{array}$ & $\begin{array}{ll}\text { BP: } & \\
\text { - } & \text { More remanufacturing spare parts } \\
\text { - } & \text { Retreading of HDOR tyres. } \\
\text { - } & \text { In } 2012 \text { Caterpillar's remanufacturing } \\
\text { programme took back over } 2.2 \\
\text { million end-of-life units for } \\
\text { remanufacturing, representing } \\
73,000 \text { tons of materials, and } \\
\text { including } 6,000 \text { different } \\
\text { remanufactured products. } \\
\text { C: } \quad \text { Disassembly and remanufacturing of } \\
\text { many newly-designed and more } \\
\text { advanced components is not } \\
\text { possible without damage. } \\
\text { Some components are still } \\
\text { systematically replaced by brand- } \\
\text { new ones: e.g. catalytic converters or } \\
\text { pneumatic brakes. }\end{array}$ \\
\hline $\mathrm{R}$ & $\begin{array}{l}\text { Design for } \\
\text { materials } \\
\text { recovery. } \\
\text { Loss of original } \\
\text { product's added } \\
\text { value. }\end{array}$ & $\begin{array}{l}\text { BP: } \\
\text { - Well-organised federation of a } \\
\text { significant part of the vehicle }\end{array}$ & BP: \\
\hline
\end{tabular}


To cite this version: Michael Saidani, Bernard Yannou, Yann Leroy, François Cluzel, Heavy vehicles on the road towards the circular economy: Analysis and comparison with the automotive industry, Resources, Conservation and Recycling, 2017, ISSN 0921-3449, http://dx.doi.org/10.1016/j.resconrec.2017.06.017.

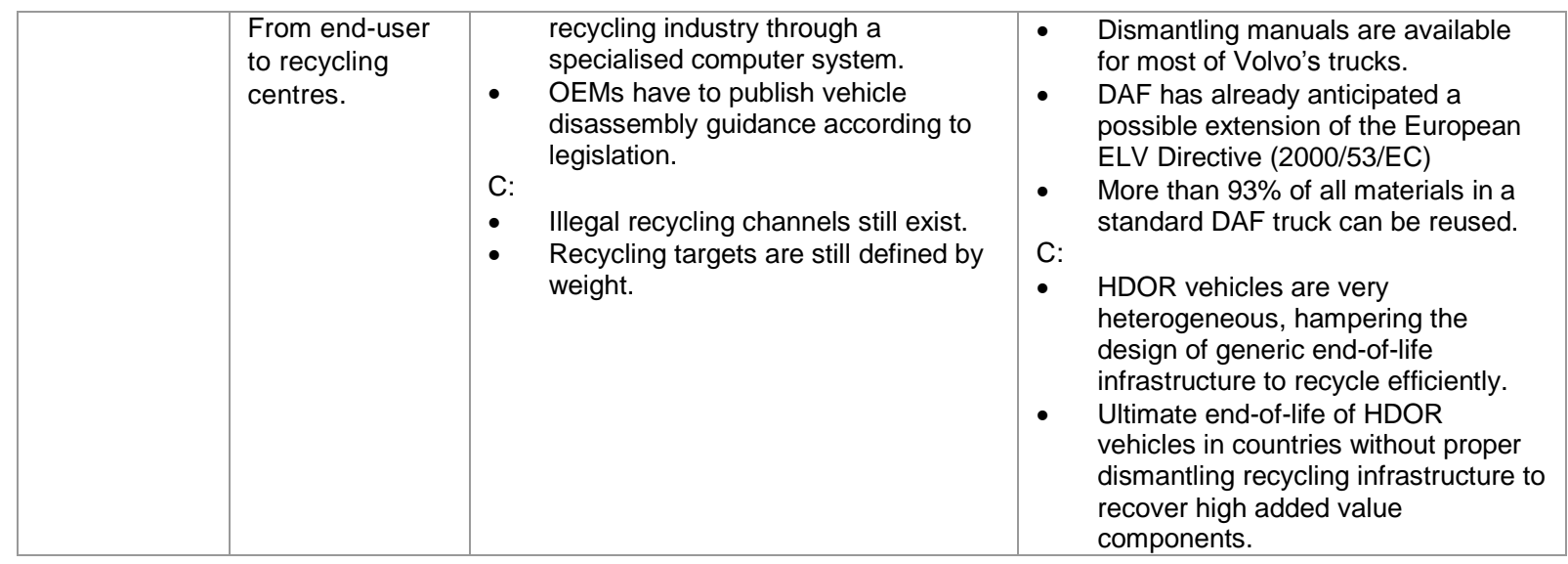

\section{DISCUSSION AND CONCLUDING REMARKS}

Globally, the implementation of the circular economy, which is still at an initial stage of development, has mainly focused on recycling rather than on reuse (Ghisellini et al., 2015). The HDOR industry case is an exception to this trend: remanufacturing is the preferred option for the EoL of HDOR vehicles, rather than dismantling and recycling. From a sustainability point of view, this is a commendable and praiseworthy practice in that it offers heavy vehicles a second life. However, second-hand heavy vehicles are then usually resold to emerging markets and developing countries that do not have the proper technologies to dismantle, recover or recycle heavy vehicles that have reached their ultimate EoL, which then become a severe burden for the environment, with loss of precious metals. Developing countries lack proper waste collection and treatment systems (Diaz, 2017), and have a number of problems related to waste management that still need to be resolved: lack of political will, absence of rules and regulations for solid waste management, insufficient funds, and absence of educational programmes.

On the other hand, even in more developed countries in Western Europe such as France, dismantling and recycling channels for heavy vehicles are in their early development stages, and it is still difficult to find and identify the relevant interlocutors and right actors (ADEME, 2006; Cetim, 2014). To date, materials recycling or recovery are therefore not the preferred pathways for the EoL of HDOR vehicles: at the European level, both industrial operators and policy makers are not proactive enough in the setting of standards related to the EoL management of HDOR equipment. In addition, the profitability of dismantling infrastructures for HDOR vehicles has yet to be proved. At the moment, exports of HDOR vehicles are profitable for the end-owners, but this is globally a non-sustainable solution, because the importing developing countries do not possess factories to recycle properly. Additionally, exports outside Europe lead to significant leakage of value for European manufacturers, from strategic, economic and environmental points of view. Simply stated, the EoL of HDOR vehicles is an important concrete opportunity for maintaining resources in Europe, and for securing the supply of rare and precious materials from resource scarcity and price volatility, which is not fully exploited today. Lastly, even if this issue is somewhat outside the scope of the present paper, European countries will have to assist developing countries in preserving value from EoL equipment and creating a circular economy (Diaz, 2017).

Major stakeholders of the HDOR industry, such as original equipment manufacturers or EoL expertise centres, are becoming increasingly aware of these missed opportunities. These challenges and opportunities had also been identified and confirmed by a business development manager from one of the main European construction equipment manufacturers, interviewed during our investigations. OEMs are beginning to understand that the stakes are high, and adapt their offers accordingly (e.g. Volvo and Caterpillar's business model evolution as detailed above). To go even further and fully achieve the potential and promises of CE, the HDOR vehicle sector can learn from the automotive sector in the following areas of best circular practices: 
To cite this version: Michael Saidani, Bernard Yannou, Yann Leroy, François Cluzel, Heavy vehicles on the road towards the circular economy: Analysis and comparison with the automotive industry, Resources, Conservation and Recycling, 2017, ISSN 0921-3449, http://dx.doi.org/10.1016/j.resconrec.2017.06.017.

- Well-organised EoL value chain of ELV in the EU. Well-established dismantling and systematic recycling procedures in ATFs, motivated and propelled by the ELV directive and EPR.

- Involvement of research and engineering expertise centres (e.g. INDRA operating in France) within the EoL value chain to help close the loops of products and materials by providing state-of-the-art tools, methods and software platforms.

- Transparent collaboration networks between automotive manufacturers, EoL treatment facilities and intermediary third parties from the EoL value chain. For instance, collaboration between industrial manufacturers all along the value chain is one of the key elements of the framework proposed by Witjes and Lozano (2016) to move effectively towards CE through more sustainable business models.

However, the mere implementation of regulations is not sufficient to ensure a smooth evolution towards sustainable CE. The example of waste electrical and electronic equipment (WEEE) is noteworthy. WEEE, which is subject to numerous regulations in Europe (e.g. Directive 2012/19/EC) is often exported, legally or illegally, "just to end up in some of the most polluted places in the world: being reprocessed under lax or no regulations to recover value via acid leaching and burning, which results in public health disasters and extensive environmental pollution in West Africa and South -East Asia" (Velis, 2015). Industrial operators (e.g. engineers, managers, designers) must be able to rely on a state-of-the-art literature on integrating and implementing circular practices. For instance, Lieder and Rashid (2016) proposed a framework to be used as a CE implementation strategy in the context of the manufacturing industry. More broadly, Moreno et al. (2016) developed a conceptual framework for circular economy design strategies (e.g. design for resource conservation, design for slowing resource loops, or design for whole systems design). This therefore gives guidance for practitioners wishing to design for new circular business models in practice.

Future research needs to go further and make a more quantitative assessment of the remaining distance that has to be gone to reach full CE for HDOR vehicles and associated spare parts. Saidani et al. (2017) provide guidelines for the design and development of new frameworks, tools and indicators for measuring product circularity. More specifically, Di Maio et al. (2017) propose a new value-based indicator to assess the performance of actors in the supply chain in terms of resource efficiency and CE. Quantification of missed value buckets for European HDOR actors should then be an enabler for both the European Commission, in considering a new regulated framework for HDOR vehicle EoL, and European industrial practitioners to exploit these opportunities gainfully. With this purpose, CIDER Engineering, an engineering centre dedicated to dismantling, recycling and remanufacturing heavy equipment and vehicles, performed a technological watch, in France and in a few strategic European countries, to (i) evaluate the quantity and deposit of EoL and second-hand HDOR vehicles, and (ii) identify last owners and intermediary third parties in the EoL value chain. According to experts from ADEME and in agreement with experts in the HDOR industry, the access to key information, such as the exact materials composition of an EoL HDOR vehicle, the current deposit stocks or the efficiency of EoL channels handling HDOR vehicles, would help bring the EoL processing of HDOR vehicles into a greener economy. It would also be useful to have real-time forecast information about the wear and tear of HDOR components in order to prevent the failure of key components, schedule more accurate preventive maintenance, and thereby contribute to circular economy implementation in practice. Further research to evaluate the environmental impact of the possible loops for each HDOR component and material will be needed to enlarge the limited amount of literature documenting this subject to date (Niero and Olsen, 2016). Each possible HDOR EoL scenario has its own consequences on the criteria of sustainability (economic, environmental and social). Also, stakeholders have their own goals and preferences regarding these criteria. The authors stress the value of all research, both theoretical and applied, experimental projects and any other initiatives that could hasten the drafting of suitable directives for end-of life HDOR vehicles, and help develop innovative processes and new control of procedures for their EoL management.

\section{ACKNOWLEDGEMENTS}

Particular thanks are due to all the experts from the automotive and HDOR industries we met during our investigations, for their time, support and invaluable shared information. The authors also thank the reviewers for their precious and highly constructive comments. 
To cite this version: Michael Saidani, Bernard Yannou, Yann Leroy, François Cluzel, Heavy vehicles on the road towards the circular economy: Analysis and comparison with the automotive industry, Resources, Conservation and Recycling, 2017, ISSN 0921-3449, http://dx.doi.org/10.1016/j.resconrec.2017.06.017.

\section{REFERENCES}

ACEA-European Automotive Manufacturers Association, 2015. ACEA Position Paper on Circular Economy. September 2015.

ACEA-European Automotive Manufacturers Association, 2016. Facts about the Automobile Industry. Available online (1 November 2016): http://www.acea.be/automobile-industry/facts-about-the-industry

ADEME, 2006. Etude sur la fin de vie de tous les moyens de transport en France, à l'exception des véhicules couverts par la directive Véhicules Hors d'Usage. Etude réalisée par BiolS pour l'ADEME, Novembre 2006.

Banaitè, D., 2016. Towards circular economy: analysis of indicators in the context of sustainable development. Social Transformations in Contemporary Society, 2016 (4), ISSN 2345-0126 (online)

Bocken, N., Bakker, C., De Pauw, I., 2015. Product design and business model strategies for a circular economy. Sustainable Design \& Manufacturing Conference, Seville, 12-14 April 2015.

Cetim, 2014. Filière de fin de vie et de déconstruction des engins lourds. Note veille, Matériels de Travaux Publics, Mines et Forage, Septembre 2014.

Chapman, A., Bartlett, C., McGill, I., Parker, D., Walsh, B., 2010. A snapshot of the remanufacturing industry in UK in 2009. CRR, Centre for Remanufacturing and Reuse, UK, August 2010.

Chemineau, L., 2011. Développement d'une méthode d'éco-conception basée sur la modélisation et l'évaluation des filières de valorisation : application au secteur automobile. PhD Thesis, Sciences de l'ingénieur [physics]. Ecole nationale supérieure d'arts et métiers - ENSAM, 2011. French. <tel-00600682>

CIRAIG, 2015. Circular Economy: A Critical Literature Review of Concepts, Bibliothèque et Archives nationales du Québec (BAnQ), August 2015. ISBN 978-2-9815420-0-7.

Clarke, R. J., 2005. Research Models and Methodologies. HDR Seminar Series, Faculty of Commerce, Spring Session 2005.

Creswell, J. W., 2003. Research design: qualitative, quantitative, and mixed methods approaches. Thousand Oaks, CA: Sage Publications, $2^{\text {nd }}$ Edition.

Creswell, J.W., Plano Clark, V.L., 2007. Designing and Conducting Mixed Methods Research. Thousand Oaks, CA: Sage.

Despeisse. M., Kishita, Y., Nakano, M., Barwood, M., 2015. Towards a Circular Economy for End-of-Life Vehicles: A Comparative Study UK - Japan. Procedia CIRP, Volume 29, 2015, Pages 668-673, ISSN 2212-8271, http://dx.doi.org/10.1016/j.procir.2015.02.122.

DfT-Department for Transport, 2016. Non-Road Mobile Machinery (NRMM) definition. Available online (1 November 2016): http://www.dft.gov.uk/vca/enforcement/non-road-mobile-mach.asp

Di Maio, F., Rem, P.C., Baldé, K., Polder, M., 2017. Measuring resource efficiency and circular economy: A market value approach, Resources, Conservation and Recycling, Volume 122, July 2017, Pages 163-171, ISSN 0921-3449, http://doi.org/10.1016/j.resconrec.2017.02.009.

Diaz, L.F., 2017. Waste management in developing countries and the circular economy. Editorial, Waste Manag. Res., Vol. 35(1) $1-2$.

Diener, D., Tillman, A.-M., 2015. Component end-of-life management: Exploring opportunities and related benefits of remanufacturing and functional recycling. Resources, Conservation and Recycling (0921-3449). Vol. 102, p. 80-93.

Diener, D., Tillman, A.-M., 2016. Scrapping steel components for recycling - Isn't that good enough? Seeking improvements in automotive component end-of-life. Resources, Conservation and Recycling, Volume 110, July 2016, Pages 48-60, ISSN 0921-3449, http://dx.doi.org/10.1016/j.resconrec.2016.03.001.

Diener, D., Williander, M., Tillman, A.-M., 2015. Product-Service-Systems for Heavy-Duty Vehicles - An Accessible Solution to Material Efficiency Improvements? Procedia CIRP, Volume 30, 2015, Pages 269-274, ISSN 2212-8271, http://dx.doi.org/10.1016/j.procir.2015.02.027.

Directive 2000/53/EC of the European Parliament and of the Council of 18 September 2000 on end-of life vehicles. Official Journal of the European Communities (21 October 2000).

Directive 2001/116/EC of 20 December 2001 adapting to technical progress Council Directive 70/156/EEC on the approximation of the laws of the Member States relating to the type-approval of motor vehicles and their trailers.

Directive 2002/151/EC: Commission Decision of 19 February 2002 on minimum requirements for the certificate of destruction issued in accordance with Article 5(3) of Directive 2000/53/EC of the European Parliament and of the Council on end-oflife vehicles.

Directive 2002/24/EC of the European Parliament and of the Council of 18 March 2002 relating to the type-approval of two or three-wheel motor vehicles and repealing Council Directive 92/61/EEC.

Directive 2002/96/EC of the European Parliament and of the Council of 27 January 2003 on waste electrical and electronic equipment (WEEE).

Directive 2003/138/EC: Commission Decision of 27 February 2003 establishing component and material coding standards for vehicles pursuant to Directive 2000/53/EC of the European Parliament and of the Council on end-of-life vehicles.

Directive 2005/293/EC: Commission Decision of 1 April 2005 laying down detailed rules on the monitoring of the reuse/recovery and reuse/recycling targets set out in Directive 2000/53/EC of the European Parliament and of the Council on end-of-life vehicles.

Directive 2005/64/EC of the European Parliament and of the Council of 26 October 2005 on the type-approval of motor vehicles with regard to their reusability, recyclability and recoverability.

Directive 2008/33/EC of the European Parliament and of the Council of 11 March 2008 amending Directive 2000/53/EC on endof-life vehicles, as regards the implementing powers conferred on the Commission.

Directive 2008/35/EC of the European Parliament and of the Council of 11 March 2008 amending Directive 2002/95/EC on the use of certain hazardous substances in electrical and electronic equipment (RoHS).

EASAC-European Academies Science Advisory Council, 2016. Indicators for a circular economy. EASAC policy report 30, November 2016. ISBN: 978-3-8047-3680-1.

EC-European Commission, 2010. Critical Raw Materials for the EU. Report of the Ad-hoc Working Group on defining critical raw materials, June 2010

EC-European Commission, 2011. Roadmap to a Resource Efficient Europe. Communication from the commission to the European parliament, the council, the European economic and social committee and the committee of the regions, Brussels, Belgium, September 2011. SEC (2011) 1067 final.

EC-European Commission, 2014a. Towards a circular economy: A zero waste programme for Europe, September 2014.

EC-European Commission, 2014b. Ex-post evaluation of certain waste stream Directive. Final Report, 18 April 2014, Bio Intelligence Service, Arcadis, Institute for European Environmental Policy. 
To cite this version: Michael Saidani, Bernard Yannou, Yann Leroy, François Cluzel, Heavy vehicles on the road towards the circular economy: Analysis and comparison with the automotive industry, Resources, Conservation and Recycling, 2017, ISSN 0921-3449, http://dx.doi.org/10.1016/j.resconrec.2017.06.017.

EC-European Commission, 2015. Closing the loop, an EU action plan for the Circular Economy, Communication from the commission to the European parliament, the council, the European economic and social committee and the committee of the regions, Brussels, Belgium, December 2015.

EC-European Commission, 2016a. Resource Efficiency. Available online (1 November 2016) http://ec.europa.eu/environment/resource_efficiency/index_en.htm

EC-European Commission, 2016b. End of Life Vehicles. Available online (1 November 2016): http://ec.europa.eu/environment/waste/elv/index.htm

EC-European Commission, ERN-European Remanufacturing Network, 2015. Remanufacturing Market Study, for Horizon 2020. Chapter 9: Heavy-Duty and Off-Road equipment, November 2015.

EEA-European Environment Agency, 2015. Circular economy in Europe - Developing the knowledge base. 37 pp., 21 x 29.7 cm, ISBN 978-92-9213-719-9, doi:10.2800/51444.

EEA-European Environment Agency, 2016. More from less - Material resource efficiency in Europe. 151 pp., 21 x $29.7 \mathrm{~cm}$, ISBN 978-92-9213-736-6, doi:10.2800/240736.

El Halabi, E., Third, M., Doolan, M., 2015. Machine-based Dismantling of End of Life Vehicles: A Life Cycle Perspective. Procedia CIRP, Volume 29, 2015, Pages 651-655, ISSN 2212-8271, http://dx.doi.org/10.1016/j.procir.2015.02.078.

EMF-Ellen MacArthur Foundation, 2013a. The Circular Economy Applied to the Automotive Industry. Available online (1 November 2016): http://www.ellenmacarthurfoundation.org/circular-economy/interactive-diagram/the-circular-economyapplied-to-the-automotive-industry

EMF-Ellen MacArthur Foundation, 2013b. Towards the circular economy - Economic and business rationale for an accelerated transition.

ERTRAC-European Road Transport Research Advisory Council, 2012. European Roadmap, Heavy Duty Truck. Report, September 2012

Eurostat, 2016. End-of-life vehicles statistics. Available online (1 November 2016): http://ec.europa.eu/eurostat/statisticsexplained/index.php/End-of-life vehicle statistics

Farel, R., Yannou, B., Bertoluci, G., 2013. Finding best practices for automotive glazing recycling: a network optimization model. Journal of Cleaner Production, Elsevier, 2013, pp.446-461, doi: 10.1016/j.jclepro.2013.02.022.

Froelich, D., Haoues, N., Leroy, Y., Renard, H., 2007. Development of a new methodology to integrate ELV treatment limits into requirements for metal automotive part design. Minerals Engineering, 20, 2007, pp. 891-901.

Garcia, J., Millet, D., Tonnelier, P., 2015. A tool to evaluate the impacts of an innovation on a product's recyclability rate by adopting a modular approach: automotive sector application. International Journal of Vehicle Design, Inderscience, 1 , pp.1-18.

Geissdoerfer, M., Savaget, P., Bocken, N.M.P., Hultink, E.J., 2017. The Circular Economy - A new sustainability paradigm? J. Clean. Prod. 143, 757-768.

Ghisellini, P., Cialani, C., Ulgiati, S., 2016. A review on circular economy: the expected transition to a balanced interplay of environmental and economic systems. J. Clean. Prod. 114, 11-32.

Gnimpieba, Z., Nait-Sidi-Moh, A., Durand, D., Fortin, J., 2015. Using Internet of Things Technologies for a Collaborative Supply Chain: Application to Tracking of Pallets and Containers. Procedia Computer Science, Volume 56, 2015, Pages 550-557, ISSN 1877-0509, http://dx.doi.org/10.1016/j.procs.2015.07.251

Hagelüken, C., Lee-Shin, J., Carpentier, A., Heron, C., 2016. The EU Circular Economy and Its Relevance to Metal Recycling. Recycling 1, no. 2: 242-253.

Hill, N., et al., 2012. EU Transport GHG: Routes to 2050 II. The role of GHG emissions from infrastructure construction, vehicle manufacturing, and ELVs in overall transport sector emissions. Available online (1 November 2016): www.eutransportghg2050.eu

Husnjak, S., Peraković, D., Forenbacher, I., Mumdziev, M., 2015. Telematics System in Usage Based Motor Insurance. Procedia Engineering, Volume 100, 2015, pp. 816-825, ISSN 1877-7058, http://dx.doi.org/10.1016/j.proeng.2015.01.436.

IBM Global Business Services Automotive, 2009. Truck 2020 transcending turbulence. Executive Report 2009, IBM Institute for Business Value.

ICCT-International Council on Clean Transportation, 2015. Overview of the heavy-duty vehicle market and CO2 emissions in the European Union. Working Paper, December 2015.

ICCT-International Council on Clean Transportation, 2016. European Vehicles Market Statistics. Pocketbook 2015-2016.

IDIS-International Dismantling Information System, 2016. Available online (1 November 2016): http://www.idis2.com/index.php?action=home\&language=english

INDRA Automobile Recycling, 2016a. Available online (1 November 2016): http://www.indra.fr/en/recycling_engineering.html INDRA Automobile Recycling, 2016b. Available online (1 November 2016): http://www.indra.fr/en/IT-solutions.html

Intel, 2015. Internet of Things Sensors Add Intelligence to Trucks. Available online (1 November 2016): http://www.intel.com/content/www/us/en/internet-of-things/customer-stories/saia-trucking-adds-intelligence-with-intel.htm

IPCC-Intergovernmental Panel on Climate Change, 2014. Climate Change 2014: Impacts, Adaptation and Vulnerability: Regional Aspects. Cambridge University Press.

IPCC-Intergovernmental Panel on Climate Change, 2015. Climate Change 2014: Mitigation of Climate Change (Vol. 3). Cambridge University Press.

Japke, O., 2009. Practice Guidelines, Development of a framework for assessing the economic benefits of remanufacturing CRR, Center for Remanufacturing \& Reuse, UK.

Kiser, B., 2016. Circular economy: Getting the circulation going. Nature, 531, 443-446, 24 March 2016.

Kwak, M., Kim, H., 2016. Modeling the Time-Varying Advantages of a Remanufactured Product: Is "Reman" Better Than "Brand New"? J. Mech. Des 138(5), 051701, Mar 11, 2016, 18 pages, Paper No: MD-14-1736; doi: 10.1115/1.4032808

Lacy, P., 2015. Growth, Innovation and Customer Value though the Circular Economy. Accenture Strategy, 2015.

Lieder, M., Rashid, A., 2016. Towards circular economy implementation: A comprehensive review in context of manufacturing industry. J. Clean. Prod, 115, 36-51.

Ma, J., Kwak, M., Kim, H. M., (2014). Demand Trend Mining for Predictive Life Cycle Design, J. Clean. Prod., 68, pp. 189-199.

Ma, J., Okudan Kremer, G., 2014. A Systematic Literature Review of Modular Product Design (MPD) from the Perspective of Sustainability, Int J Adv Manuf Technol, 86: 1509. doi:10.1007/s00170-015-8290-9.

Manitou Group, 2016. Handling your world. Annual Report 2015. May, 2016.

Matexchange, 2016. Available online: (accessed on 1 November 2016): http://www.matexchange.fr/

MGI- McKinsey Global Institute, 2013. Resource Revolution: Tracking global commodity markets. McKinsey Sustainability \& Resource Productivity Practice, September 2013.

MGI-McKinsey Global Institute, 2015. Europe's Circular Economy Opportunity, Report, September 2015. 
To cite this version: Michael Saidani, Bernard Yannou, Yann Leroy, François Cluzel, Heavy vehicles on the road towards the circular economy: Analysis and comparison with the automotive industry, Resources, Conservation and Recycling, 2017, ISSN 0921-3449, http://dx.doi.org/10.1016/j.resconrec.2017.06.017.

Michelin, 2016. Michelin Challenge Bibendum Community, Vehicles and the Circular Economy. Available online (1 November 2016): https://community.michelinchallengebibendum.com/docs/DOC-2364

Millet D., Yvars P.A., Tonnelier P., 2012. A method for identifying the worst recycling case: Application on a range of vehicles in the automotive sector. Resources, Conservation and Recycling, Volume 68, November 2012, Pages 1-13, ISSN 09213449, http://dx.doi.org/10.1016/j.resconrec.2012.07.002.

Moreno, M., de los Rios, C., Rowe, Z., Charnley, F., 2016. A Conceptual Framework for Circular Design. Sustainability, 8, 937.

Niero, M., Olsen, S.I., 2016. Circular economy: To be or not to be in a closed product loop? A Life Cycle Assessment of aluminium cans with inclusion of alloying elements, Resources, Conservation and Recycling, Volume 114, November 2016, Pages 18-31, ISSN 0921-3449, http://doi.org/10.1016/j.resconrec.2016.06.023.

NSTSCE-National Surface Transportation Safety Center for Excellence, 2012. Market Guide to Fleet Telematics Services, Creating a Consumer's Guide to Currently Available Aftermarket Solutions. Tammy E. Trimble \& Darrell S. Bowman, December 2012.

Parto, S., Loorbach, D., Lansink, A., 2017. Transitions and institutional change: the case of the Dutch waste subsystem. In: Industrial Innovation and Environmental Regulation.

Poulikakos, L.D., Heutschi, K., Soltic, P., 2013. Heavy duty vehicles: Impact on the environment and the path to green operation. Environmental Science \& Policy, Volume 33, November 2013, Pages 154-161, ISSN 1462-9011, http://dx.doi.org/10.1016/j.envsci.2013.05.004.

Recycling, 2016. Available online (1 November 2016): http://www.recycling.com/downloads/waste-hierarchy-lansinks-ladder/

Regulation (EC) No 1907/2006 on the Registration, Evaluation, Authorisation and Restriction of Chemicals (REACH) and setting up a European Chemicals Agency

Reuter, M.A., van Schaik, A., Ignatenko, O., de Haan, G.J., 2006. Fundamental limits for the recycling of end-of-life vehicles. Minerals Engineering, Volume 19, Issue 5, April 2006, Pages 433-449.

Saidani, M., Yannou, B., Leroy, Y., Cluzel, F., 2017. How to Assess Product Performance in the Circular Economy? Proposed Requirements for the Design of a Circularity Measurement Framework. Recycling, 2, 6.

Sauvé, S., Bernard, S., Sloan, P., 2016. Environmental sciences, sustainable development and circular economy: Alternative concepts for trans-disciplinary research. Environmental Development, Volume 17, January 2016, Pages 48-56, ISSN 2211-4645, http://dx.doi.org/10.1016/j.envdev.2015.09.002.

Sievers, H., Tercero, L., 2012. European dependence on and concentration tendencies of the material production. Polinares, EU Policy on Natural Resources, March 2012.

Simic, V., 2013. End-of-life vehicle recycling - A review of the state-of-the-art. Tehnički vjesnik - Technical Gazette 20. 2. 2013. p. 371-380.

Simic, V., 2015. A two-stage interval-stochastic programming model for planning end-of-life vehicles allocation under uncertainty. Resources, Conservation and Recycling, Volume 98, May 2015, Pages 19-29, ISSN 0921-3449, http://dx.doi.org/10.1016/j.resconrec.2015.03.005.

Snodgress D., 2012. Sustainable development - Our focus \& commitment. Cat Reman, Septembre 2012.

Toyota, 2016. Available online: https://www.toyota-europe.com/world-of-toyota/feel/environment/better-earth/recycle

Tukker, A., 2015. Product services for a resource-efficient and circular economy - a review. Journal of Cleaner Production, Volume 97, 15 June 2015, Pages 76-91, ISSN 0959-6526, http://dx.doi.org/10.1016/j.jclepro.2013.11.049.

Tukker, A., Cohen, M. J., 2004. Industrial Ecology and the Automotive Transport System. Journal of Industrial Ecology, 8: 1418. doi:10.1162/1088198042442324

UNECE-United Nations Economic Commission for Europe, 2016. Heavy-Duty Vehicles Classification in Europe. Available online (1 November 2016): http://www.unece.org/trans/main/wp29/wp29wgs/wp29gen/wp29classification.html

USDoE-US Department of Energy, 2013. Energy Efficiency \& Renewable Energy, Workshop Report: Trucks and Heavy-Duty Vehicles Technical Requirements and Gaps for Lightweight and Propulsion Materials. February 2013.

USDoT-US Department of Transportation, 2014. Study of the Impact of a Telematics System on Safe and Fuel-efficient Driving in Trucks, April 2014.

USITC-US International Trade Commission, 2012. Remanufactured Goods: An Overview of the U.S. and Global Industries, Markets, and Trade. Chapter 4: Heavy-Duty and Off-Road (HDOR) Equipment, Investigation No. 332-525, USITC Publication 4356, October 2012.

Velis, C.A., 2015. Circular economy and global secondary material supply chains. Editorial, Waste Manag. Res., Vol. 33(5) 389391.

Velis, C.A., Vrancken, K.C., 2015. Which material ownership and responsibility in a circular economy? Editorial, Waste Manag. Res., Vol. 33(9) 773-774.

Volvo Group, 2015. The Volvo Group Annual and Sustainability Report 2015. Report, pp. 22.

Volvo Truck Corporation, 2012. Disassembly instructions, complete vehicle. Service Information, Volvo Truck Corporation, Göteborg, Sweden, 2012.

Walker, G., Manson, A., 2014. Telematics, urban freight logistics and low carbon road networks. Journal of Transport Geography, Vol. 37, pp. 74-81.

Walnum, H.J., Simonsen, M. 2015. Does driving behavior matter? An analysis of fuel consumption data from heavy-duty trucks. Transportation Research Part D: Transport and Environment. Volume 36, May 2015, pp. 107-120.

Walsh, B., 2013. Remanufacturing in Europe - The business case. CRR, Centre for Remanufacturing and Reuse, UK, May 2013.

Weiland, F.W., 2014. European remanufacturing of heavy-duty and off-road vehicle components (including tyres): a hidden giant? FWJ Consulting, May 2014.

Wells, P., Orsato, R. J., 2005. Redesigning the Industrial Ecology of the Automobile. Journal of Industrial Ecology, 9: 15-30. doi:10.1162/1088198054821645

Wilts, H., Von Gries, N., Bahn-Walkowiak, B., 2016. From Waste Management to Resource Efficiency - The Need for Policy Mixes. Sustainability, 8, 622.

Witjes S., Lozano R., 2016. Towards a more Circular Economy: Proposing a framework linking sustainable public procurement and sustainable business models. Resources, Conservation and Recycling, Volume 112, September 2016, Pages 37-44, ISSN 0921-3449, http://dx.doi.org/10.1016/j.resconrec.2016.04.015.

Yi, H-C., Park, W.J., 2015. Design and Implementation of an End-of-Life Vehicle Recycling Center Based on loT (Internet of Things) in Korea. Procedia CIRP, Volume 29, 2015, Pages 728-733, ISSN 2212-8271, http://dx.doi.org/10.1016/j.procir.2015.02.007. 
To cite this version: Michael Saidani, Bernard Yannou, Yann Leroy, François Cluzel, Heavy vehicles on the road towards the circular economy: Analysis and comparison with the automotive industry, Resources, Conservation and Recycling, 2017, ISSN 0921-3449, http://dx.doi.org/10.1016/j.resconrec.2017.06.017.

\section{APPENDIX A - QUESTIONNAIRE}

The semi-structured interview guide used to discuss circular economy implementation with automotive and HDOR actors, was divided into four main sections:

i. General information about the actor and company questioned, including company name, activity, size and geographical location, background, business model(s), suppliers and clients, existing collaborations, vehicle types.

Q\#0: In a word, what are the current main needs and issues you have to deal with?

ii. Regulatory aspects, including current regulations to be complied with, and anticipation of upcoming regulations.

Q\#1: What are the current regulations you have to comply with?

Q\#2: What are your strategies to deal with upcoming or future regulations?

Q\#3: Do you have any interest in an extension of ELV Regulations to Heavy Vehicles?

iii. Management of life cycle, including: pre-life (design, manufacturing, logistics), life (use, maintenance, upgrading), end-of-life (reuse, recovery, remanufacturing, refurbishing, recycling, disposal), and integration of emerging technologies.

Q\#4: In which steps of the life cycle of HDOR Vehicles is your company involved?

Q\#5: What are the highest value components or operations, in terms of cost, environmental impact, complexity, and technology? Are your systems "eco-designed"? Easy to disassemble? Q\#6: What are the types of systems that fail most often? What are the parts that require most maintenance?

Q\#7: Are your systems well designed and dimensioned for your purpose of usage? What parts have evolved a lot since you have been using HDOR vehicles? What parts need some upgrade according to your experience; what could be improved to facilitate maintenance or efficiency during usage?

Q\#8: Do you get any feedback during the use phase from the customer or user, for real use or perception? If so, how? If not, do you think it could be of interest for your operations?

Q\#9: What is the fate of your systems (vehicles, components, materials) at their end-of-life (EoL), when they no longer function?

Q\#10: Do you propose second-hand systems (vehicles, components, materials) in your business operations? Examples?

Q\#11: Do you make money from the EoL of your system? How? Who with? Do you collaborate with EoL recycling channels, operators or exporters? Examples?

Q\#12: Are you aware of new technologies such as Telematics, Internet of Things, and Big Data in your industrial field? If so, are you aware of the benefits they could bring to your organisation? Q\#13: Have you already implemented such devices in your systems or practices? Do you use them? What do they bring your organisation (positive or negative)? If so, what devices, for what purposes? If not, are you planning to use them in the (near) future?

iv. Sustainability issues and circular economy positioning, including social and economic situations, environmental concerns and circular economy transition.

Q\#14: What could be improved regarding the social or economic dimensions of your companies? Do you have any KPIs (Key Performance Indicators) to measure these aspects? Q\#15: Are you currently undertaking or planning to undertake any environmental actions? Examples? Have you heard of the ISO 14001 certification?

Q\#16: What is the main reason, or trigger for these actions? Environmental sensitivity, economic benefits, pressure from customers or regulations, or profitability of selling green products?

Q\#17: Are you aware of the Circular Economy model, and of the opportunities and benefits it could bring you?

Q\#18: What could/should be done at your level to move towards a more efficient circular model?

The above generic questionnaire served as a guide but was adapted for each interview. The following companies, agencies and persons were interviewed: raw materials national expert from ADEME (French environmental agency), end-of-life transportation means coordinator from ADEME, project manager from INDRA (precursor and leading player in vehicle recycling in France), director manager from CIDER Engineering (private agency expert HDOR dismantling), director manager from TORA Location (NRMM rental company), road construction site supervisor from COLAS (major user of NRMM), sustainable development manager from MANITOU (handling equipment manufacturer). 